Article

\title{
Applications of Geophysical Surveys for Archaeological Studies in Urban and Rural Areas in Czech Republic and Armenia
}

\author{
Jaroslav Bárta ${ }^{1, *}$, Tomáš Belov ${ }^{1}$, Jan Frolík ${ }^{2}$ and Jaroslav Jirků ${ }^{1}$ \\ 1 G IMPULS Praha Ltd., J. Nerudy 232, 25261 Jenec, Czech Republic; belov@gimpuls.cz (T.B.); \\ jirku@gimpuls.cz (J.J.) \\ 2 Institute of Archaeology of the CAS, Prague, Letenska 123/4, 11801 Praha, Czech Republic; \\ frolik@arup.cas.cz \\ * Correspondence: barta@gimpuls.cz; Tel.: +420-724-066-550
}

Received: 8 August 2020; Accepted: 1 September 2020; Published: 5 September 2020

\begin{abstract}
The authors of the presented paper tested the possible use of geophysical methods in the field of archaeological and constructional-historical research. It focused on the historical center of Prague, where we took measurements in the built-up areas covered by cobble stones and asphalt. The works were carried out mainly at the Old Town Square, Hradčany Square, Charles Square and Lesser Town Square. Field conditions were completely different at the Armenia sites (intact agricultural areas). We used the methods of shallow geophysical survey, namely geoelectrical methods, gravimetry, seismics and magnetometry. Measurement results from the built-up areas were affected by presence of engineering networks, transportation and field obstacles. Working in the rural areas is generally less demanding in terms of implementation and evaluation, but our results show that proper selection of geophysical methods brings positive results even in urban areas. The research proved that good results can be expected if one uses multiple geophysical methods measuring various physical properties of an environment. The application of only one, albeit sophisticated method, is usually not enough. There is a necessity to improve interpretational software for the purposes of archaeological object detection. The objects are mainly buried within the first meters and are relatively small. Contrast of physical properties between searched objects and their surrounding environment does exist but typically is small and, therefore, it is necessary to measure multiple physical parameters simultaneously. The presented projects aimed not only to archaeology, but the results also had practical outputs for public administration and development.
\end{abstract}

Keywords: near surface geophysics; shallow geophysical survey; archaeology; interpretation; urban area; rural area; COST Action SAGA (CA17131)

\section{Introduction}

This paper deals with using a set of geophysical methods for archaeological or constructionalhistorical research (for examples of the cooperation between both disciplines, see Frolík [1] and Reynolds [2]). Geophysical methods in archaeology have being carried out widely for decades (Conyers [3], Deiana [4], Gad Ej-Oedy [5] and Oswin [6]). The electrical resistivity tomography (ERT) method in archaeology shows (Ekincy [7]) who uses the 3D display of ERT results. Another possible method may be the ground penetrating radar (GPR), like in (Beresneva [8]). The success rate of routinely carried out magnetometry in archaeology is evaluated in (Almutari [9]). Brion [10] compares geophysical data with archaeological conclusions with respect to spatial analysis. For successful use of geophysics in archaeology, it needs to be based on the deeper theoretical basics of geophysical methods-one 
cannot rely only on the superficial manuals of the geophysical instruments' manufacturers to operate an instrument. Currently, the very topical issue of shallow seismic reflection is described in detail in Baker [11]. The basics of geophysical methods in the level of current knowledge are described by Butler [12] and Everett [13].

The authors of the presented paper state the findings use of geophysical methods at four squares in the historical downtown of Prague and at historically important sites in Armenia (Armavir province). While the Armenian sites were placed in country areas with practically no buildings, transportation nor engineering networks, the Prague sites are covered with cobblestones and are affected by strong transportation and underground engineering networks (cables, pipelines, etc.).

The results of the Armenian and Prague research works were presented as separate presentations (described in detail) within the SAGA Workshop Prague-Czech Republic (2019) and more detail can be found in the presentations of Barta [14], Barta [15] and Jirku [16].

The main goal of the works in the Prague center was bringing findings via non-destructive methods, working not only for one particular piece of archaeological research, but to make an information database for other city development-related activities, i.e., revitalization of free spaces, mapping out historically valuable sections that should not be destroyed via building activities in future, etc. The Armenia works aimed mainly to optimize the projects, leading to documentation and preservation of archaeologically important sites which are currently endangered by an on-going industrialization and vivid housing development. Thanks to extensive field measurements, extensive experience was gained, which allowed evaluation of multiple geophysical techniques in various field conditions and getting a picture of pros and cons of these techniques.

\section{Materials and Methods}

\subsection{Study Areas}

In Prague four main large squares in the historical center were chosen (Figure 1). All sites are characterized by a strong transportation and business and touristic activities.

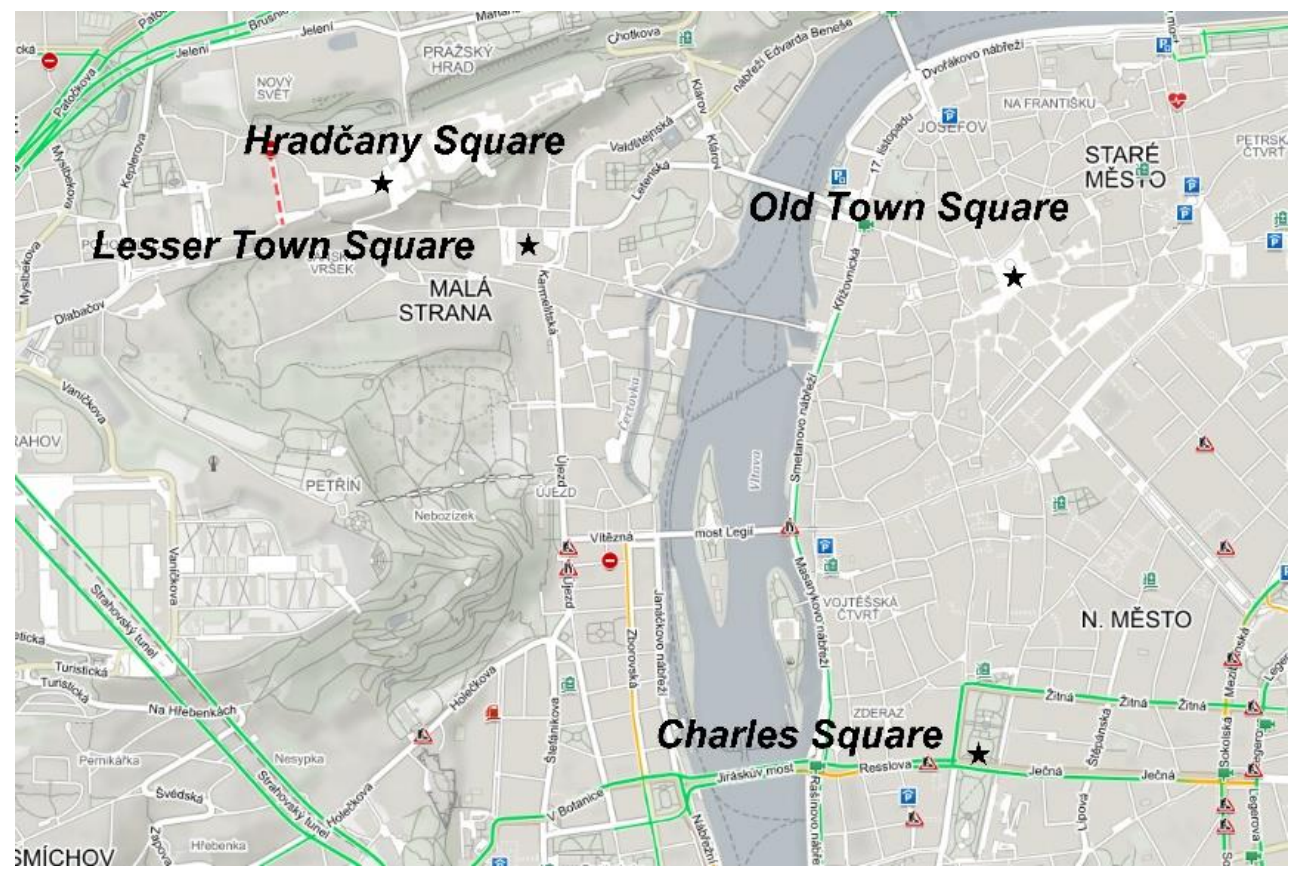

Figure 1. The historical center of Prague with position of studied areas (squares). 


\subsubsection{Charles Square (Karlovo Náměstí)}

The main goal of the works at the Charles Square was to detect potential remains of the Holy Body Chapel and check the existence of a graveyard in its vicinity (Podliska [17]). The gothic building of the chapel worked for safekeeping and exhibiting of the crown jewels during the reigning of the emperor Charles IV (1346-1378 AD). There were assumptions that the chapel's foundations may lay under a frequent road with a strong tram and car transportation. The road is mainly covered by asphalt; additionally, there are rails of the tram track in the road (Figure 2). The geophysical works were carried out due to proposed pedestrian subway within the revitalization project. The city council conditioned the building of a subway to prevent from any potential collisions with the chapel's foundations or local burial area.

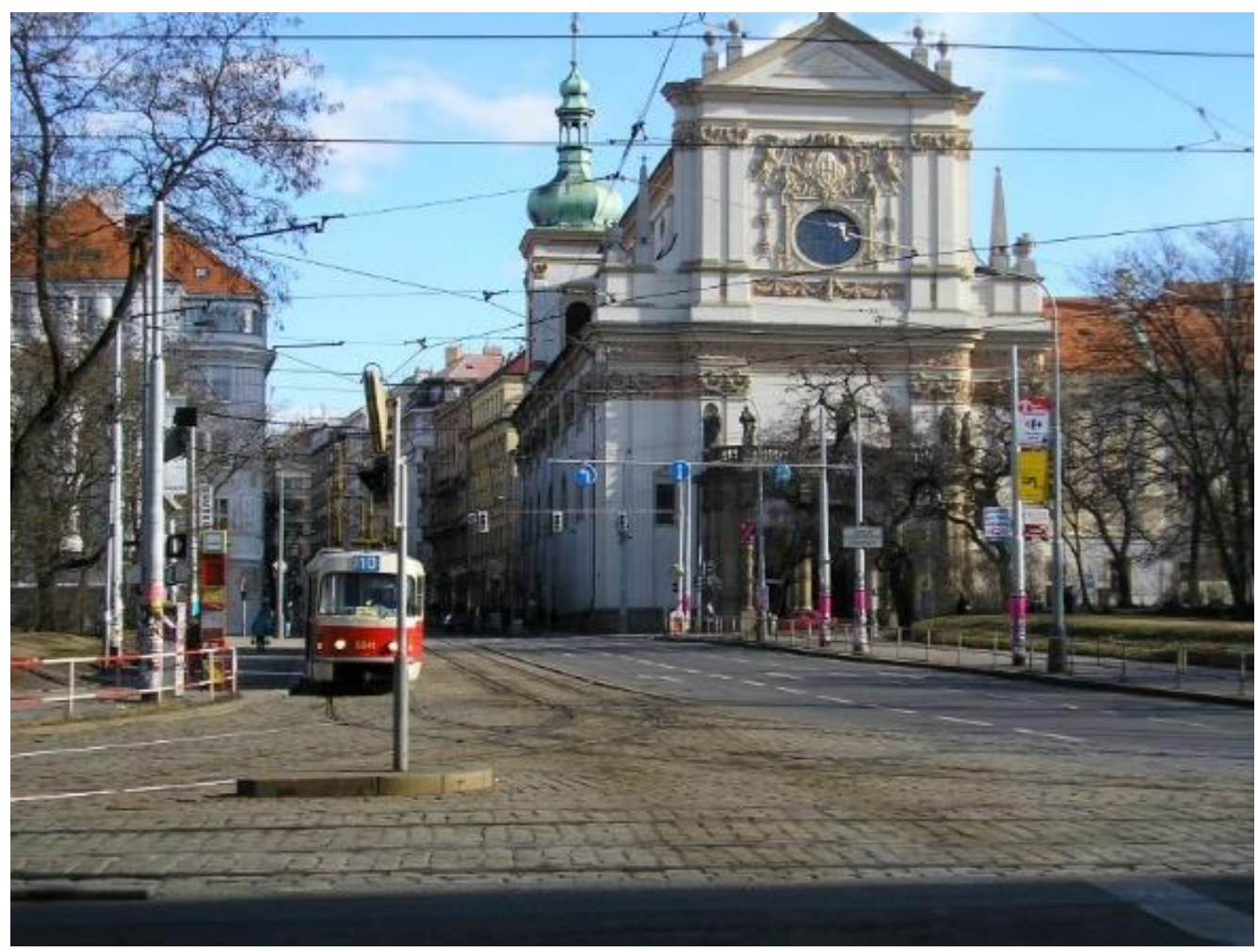

Figure 2. Center of the Charles Square with St. Ignac Church. Remains of the Holy Body Chapel were situated under tram rails and tram stop.

\subsubsection{Old Town Square (Staroměstské Náměstí)}

The Old Town Square represents a relatively free space with a large memorial of Jan Hus (one of the first reformers of the Church) in its center (Figure 3). Nearby, the memorial a recently built-up replica of the Maria Pillar stands (was built on the original building's foundations). The Old Town Square has a long history mainly connected to the era of gothic architecture (Figure 4). The older cultural layers are interfered by younger activities (Havrda [18]). During the 20th century, a tram track was passing through the center of the square but was removed in the 50th. The site was intersected by the excavation works for a concurrent water pipeline, sewage and cable lines. The tubes of the metro line and technical tunnels lie deeper under the cultural layers. The main reason for carrying out the geophysical measurements was to identify the current state of geological bedrock via non-destructive methods with respect to potential historical objects. These findings are being used by archaeologists and the city council's members for planning technical activities at the square. 


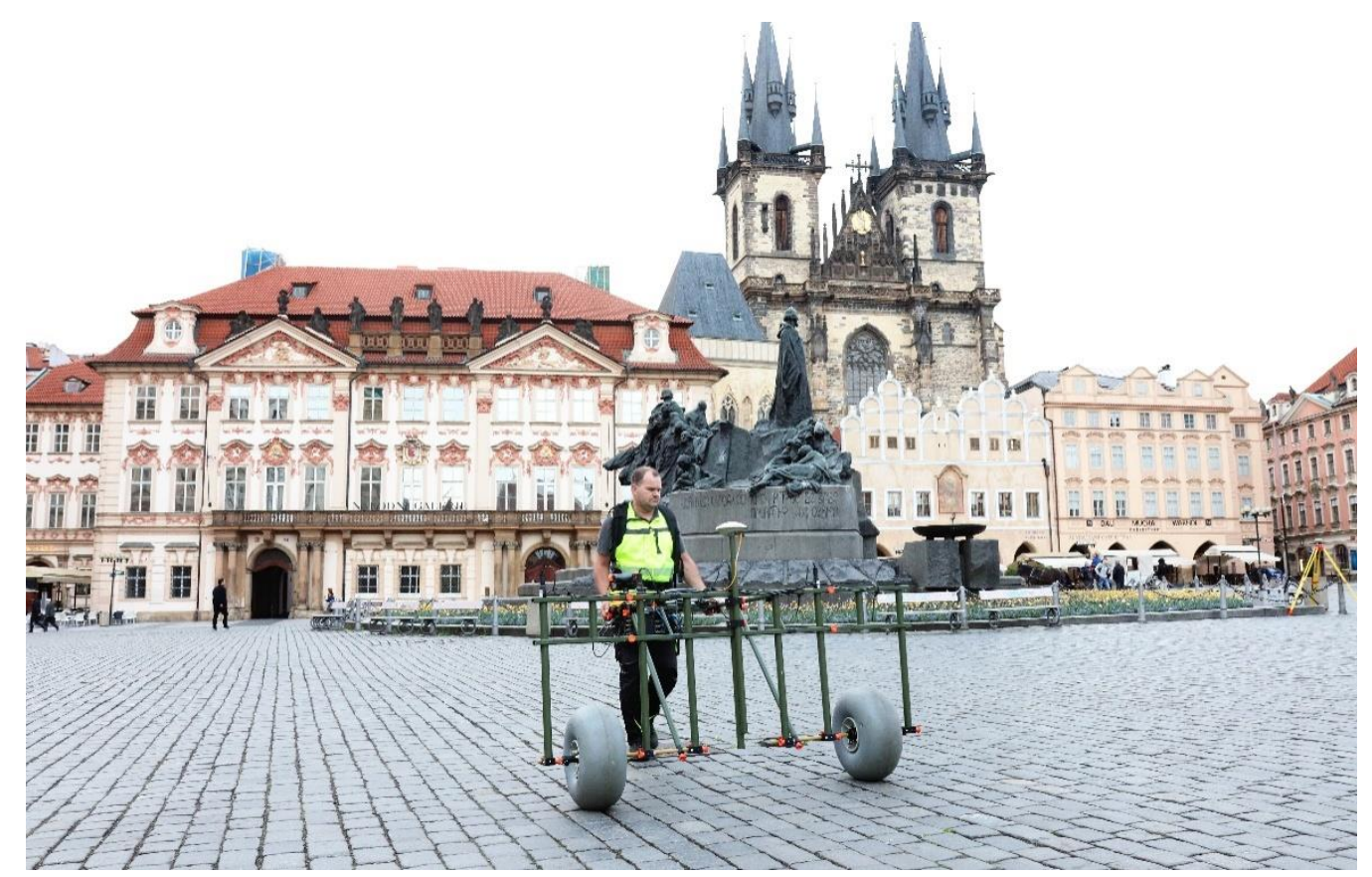

Figure 3. The Old Town Square, monument of Jan Hus, Church of Mother of God before Týn and in foreground the Magneto MXPDA magnetometry system (Sensys).

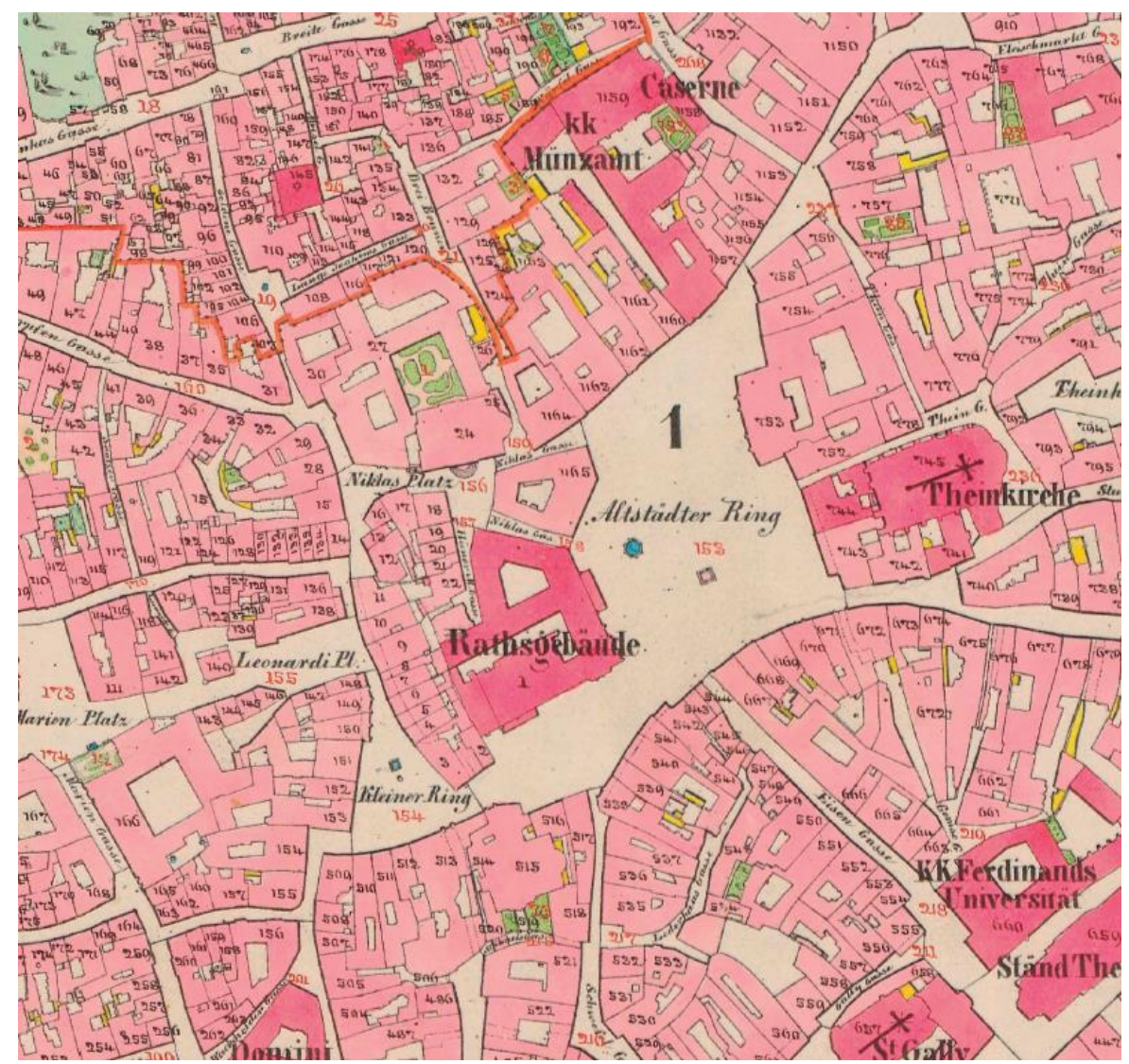

Figure 4. The map of the Old Town Square ("Altstädter Ring") from 1842 (by CUZK, the State Administration of Land Surveying and Cadastre). 


\subsubsection{Hradčany Square (Hradčanske Náměstí)}

The Hradčany square lies in a close proximity of the Prague Castle (Figure 5) and, since the 1980s, has been extensively archaeologically researched. The square has not been exposed to any remarkable building activity in the modern age. Apart from the rescue archaeological survey in the central part in 1944, no significant spatial outcrops were carried out, but only documentation of the engineering networks' linear outcrops (Blažková [19], Mašterová [20]). From a geophysicist's point of view, we can consider the square as a mainly non-built-up area with a park in its middle. The most important activity changing the original state-of-manner of the square is probably the fire water pool made in 1944, providing water in the end of World War II. During its construction, a Romanesque living house was found and partly disrupted (Frolík [21]). After World War II, the pool was destroyed.

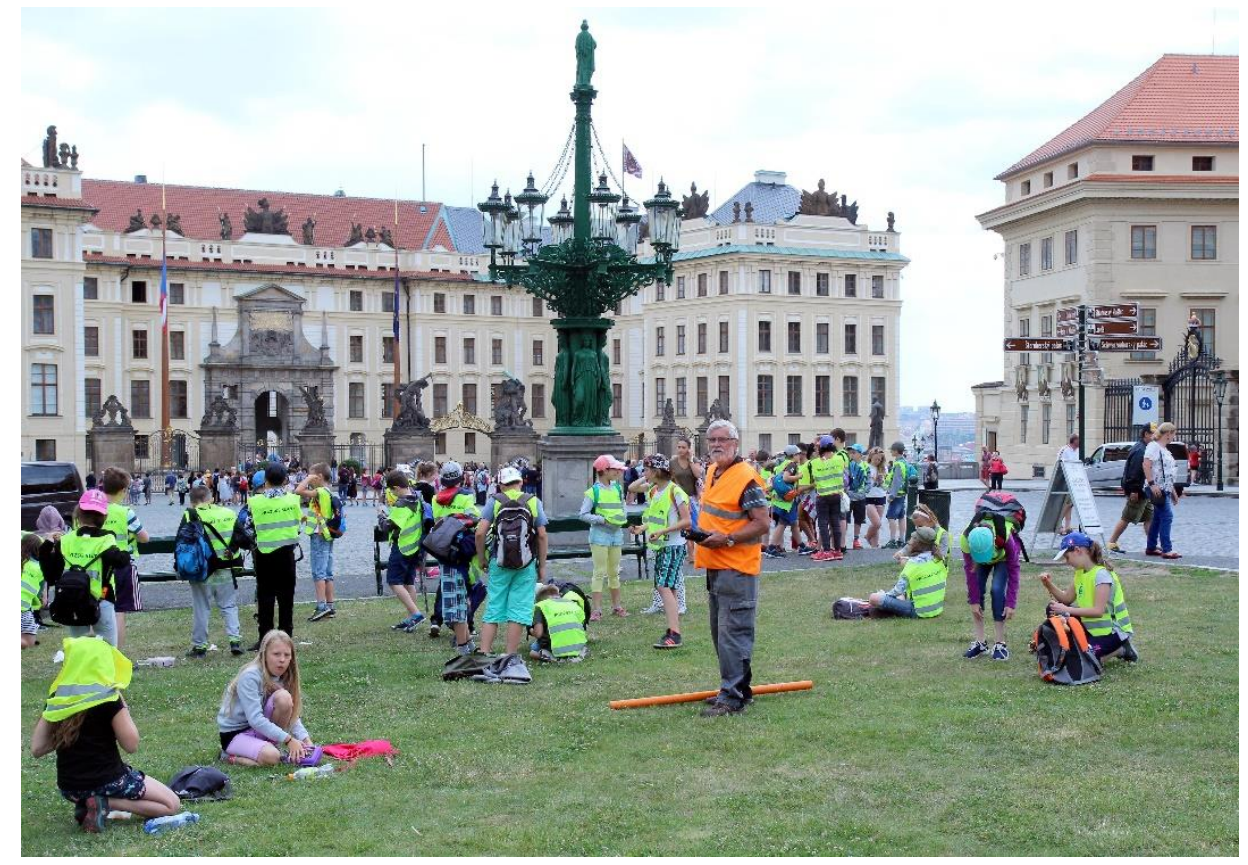

Figure 5. The Hradčany Square. In the foreground is our geophysicist with the CMD-MiniExplorer instrument.

The square is being visited by tourists during the day (Figure 5); hence, most of the works were carried out in night. The main goal of the geophysical measurements at the square was verification of the presence of several assumed archaeological objects, mainly stone buildings from the 12th and 13th centuries (and also medieval trenches). Gaining findings for newly planned construction activities was not crucial here, as there are no ongoing plans for the square's revitalization.

\subsubsection{Lesser Town Square (Malostranské Náměstí)}

The Lesser Town Square is composed of so-called Upper and Lower square (Figures 6 and 7). The Lower one makes the eastern and the Upper one the western part. The lower square is intersected by the city tram lines. There are extensive transportation and tourist activities at the square. The last significant action within the square was the fire water tank built in the end of World War II, covering approximately half of the Lower square. 


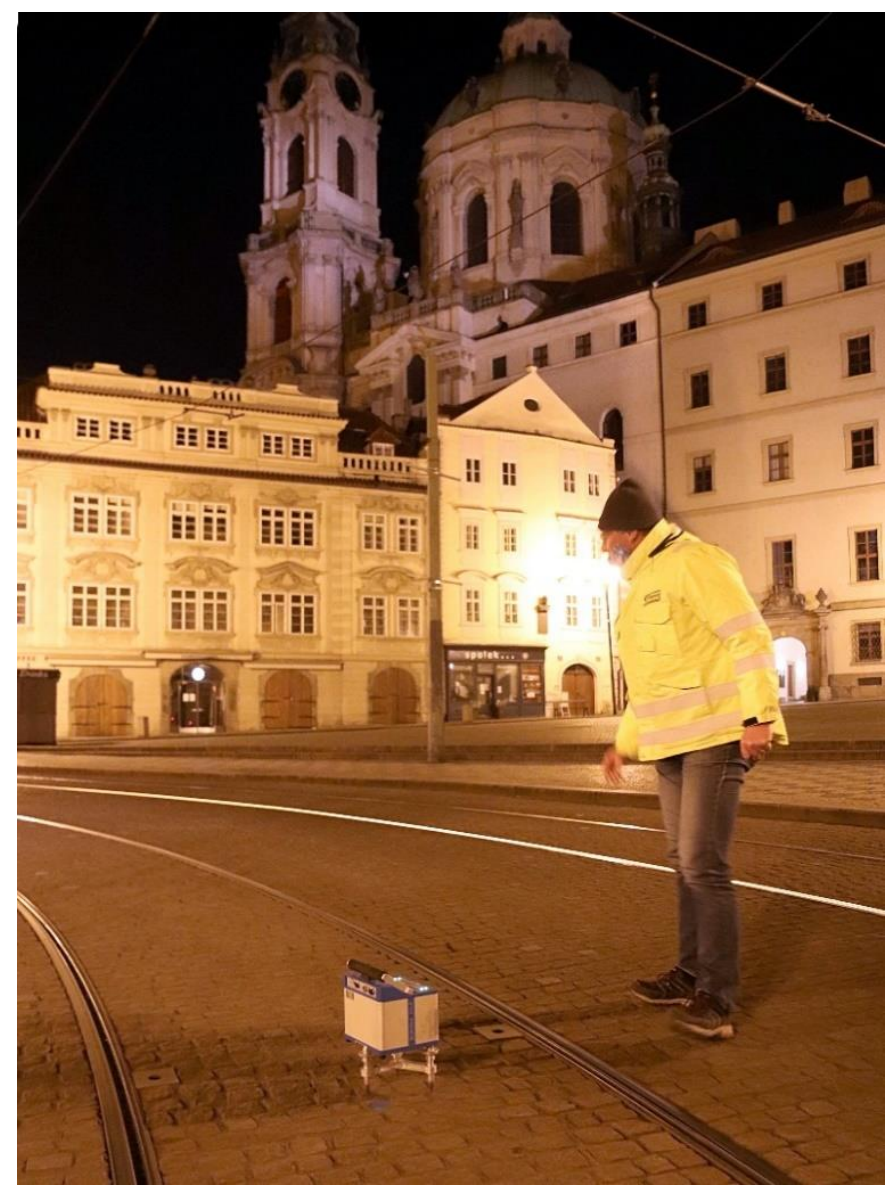

Figure 6. Lesser Town Square with a gravimeter.

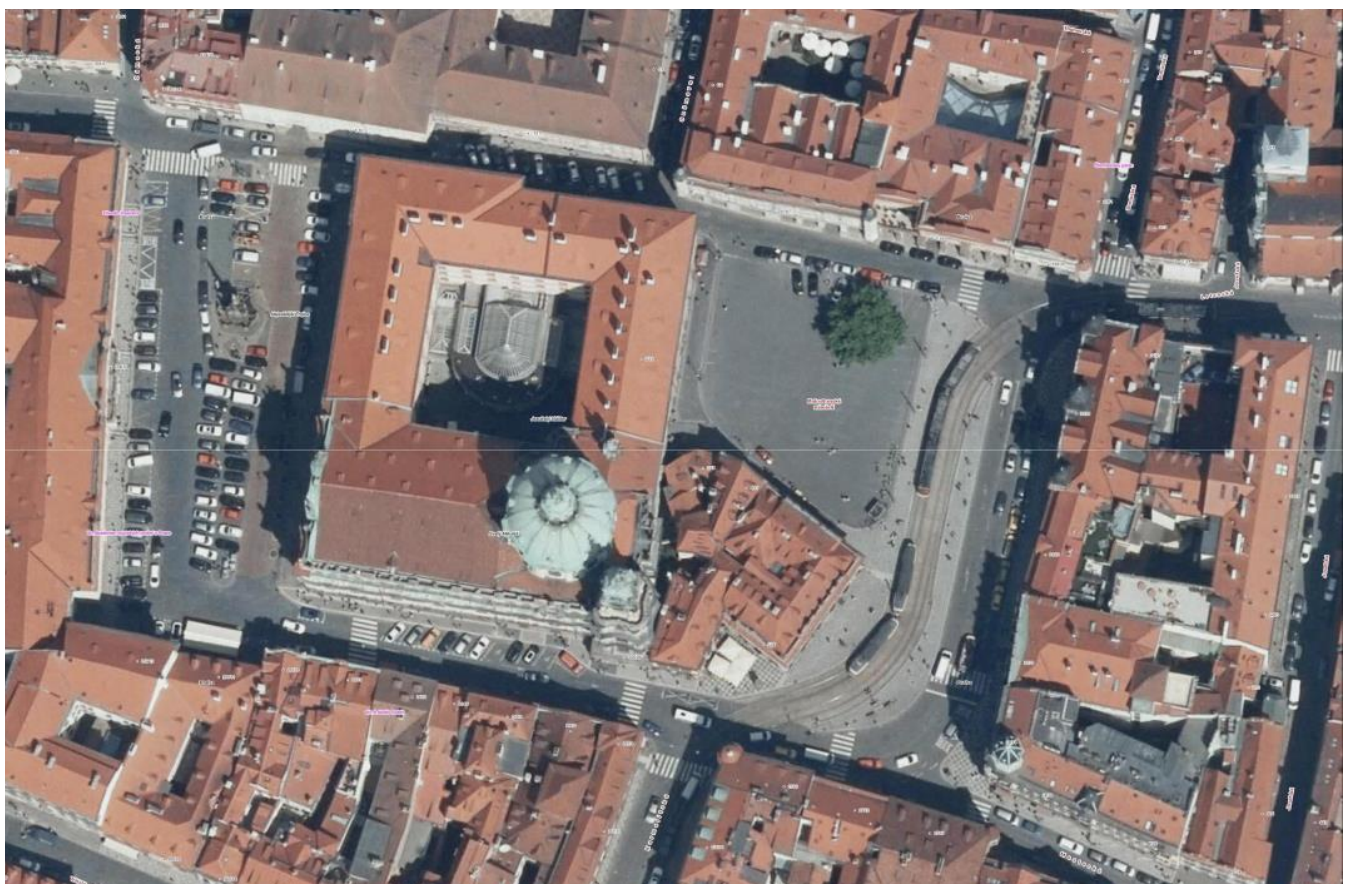

Figure 7. Lesser Town Square (aerial photograph) with the eastern and western parts. 
The goal of the measurements was to bring an overall geophysical picture of the square in the limits of local technical and transport conditions. The findings are intended for the needs of archaeological research but also for preparing the revitalization of these areas.

The area of the Lesser Town Square belongs, from an archaeological point of view, to the key areas of the oldest settlement of the left-bank suburb of the Prague castle. The settlement of current Lesser Town is proved to be older than of the inhabitants of the opposite bank of the Vltava river, i.e., the current Old Town (Čiháková [22,23] a Cymbalak [24]).

\subsubsection{Armenian Sites}

The goal of the Armenia-based activities was to help in developing the Armavir province, namely in the field of tourism and ecology. Three joint geophysical and archaeological expeditions were organized. The geophysical investigation was arranged as preliminary study which can open bigger next projects in Armenia. During these expeditions, the survey works were carried out at pre-chosen archaeologically interested sites (Simonyan [25] and Avestisyan [26]). While doing this, the first business negotiations were conducted (heads of the province, Ministry of the culture of Armenia and Institute of the archaeology and ethnography of the National academy of science of the Republic of Armenia).

The Armavir province lies in the western rim of the country (Figure 8). Studied settlement sites were preliminary dated to the Bronze Age or Iron Age. The sites were made of the volcanic rocks (Figure 9).

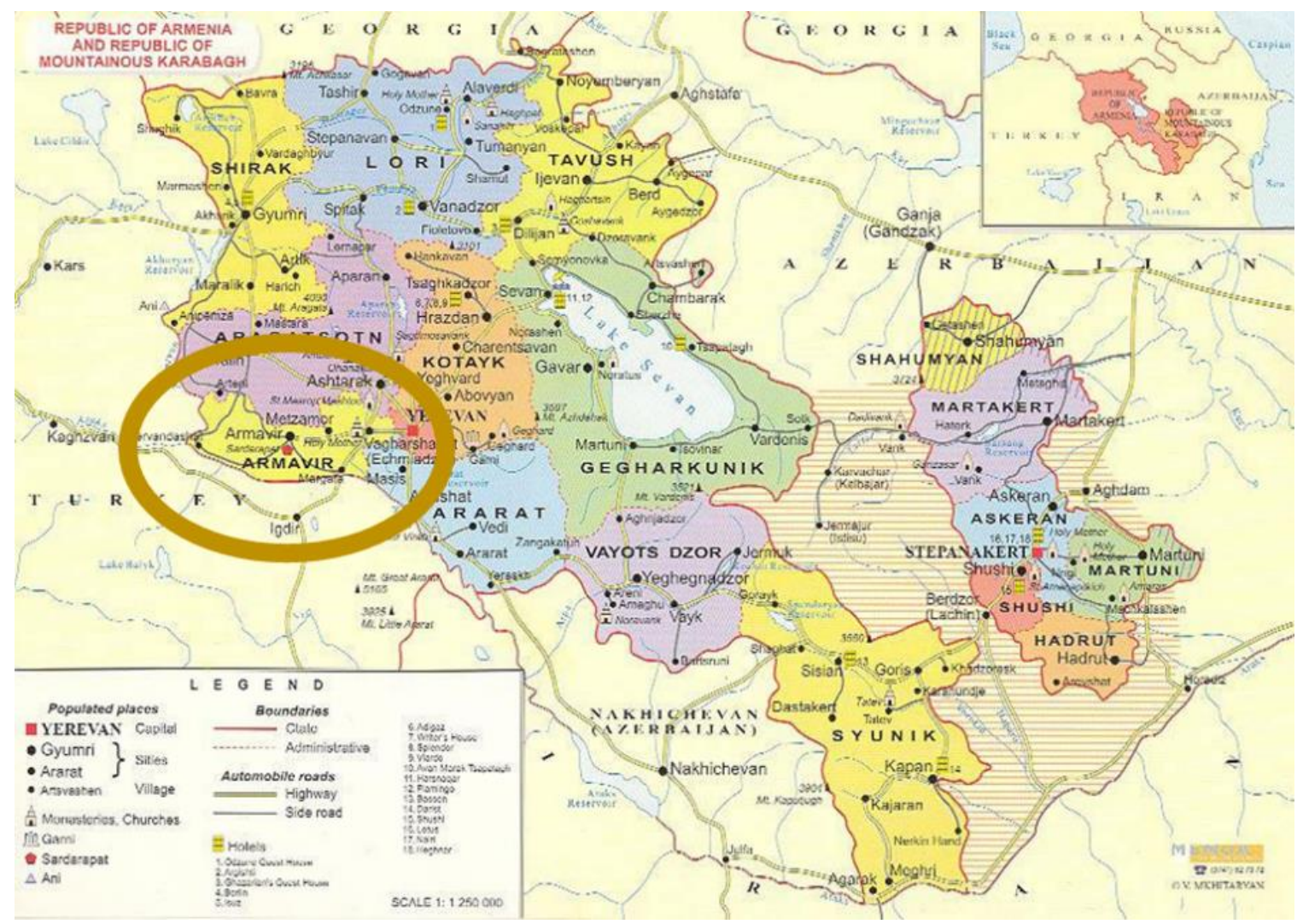

Figure 8. Map of Armenia, Armavir province. 


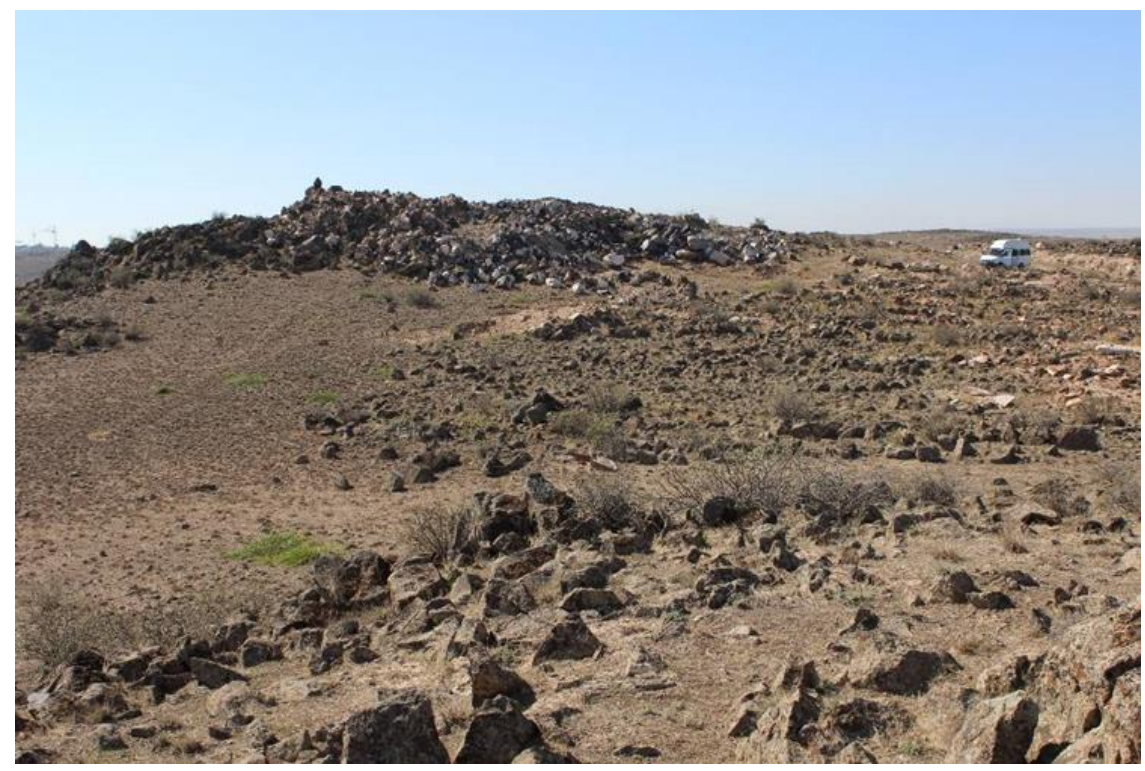

Figure 9. Armenia, Armavir province, Aygeshat site with traces of Iron Age cemetery.

\subsection{Methodology}

Within the geophysical research works, a set of geophysical methods, adapted to given tasks and technical possibilities, was used.

\subsubsection{Magnetometry}

The magnetometric measurements were carried out in the form of observing the vertical gradient of the magnetic field. All Armenian sites and a part of the Old Town Square were measured via the proton PGM-1 (manufacturer SatisGeo, Brno, Czech Republic) gradient meter (Figure 10). For the other tasks, the Magneto MXPDA by Sensys was used (Figure 2). In the most difficult places to pass through the field, the Magneto system enables the single-channel mode as well. The Magneto MXPDA is also a gradient meter system but with fluxgate sensors. The motion of both instruments in the field was mapped via GPS. In some cases, we encountered a loss of the GPS signal and the geophysical profiles had to be leveled via classic geodetic techniques.

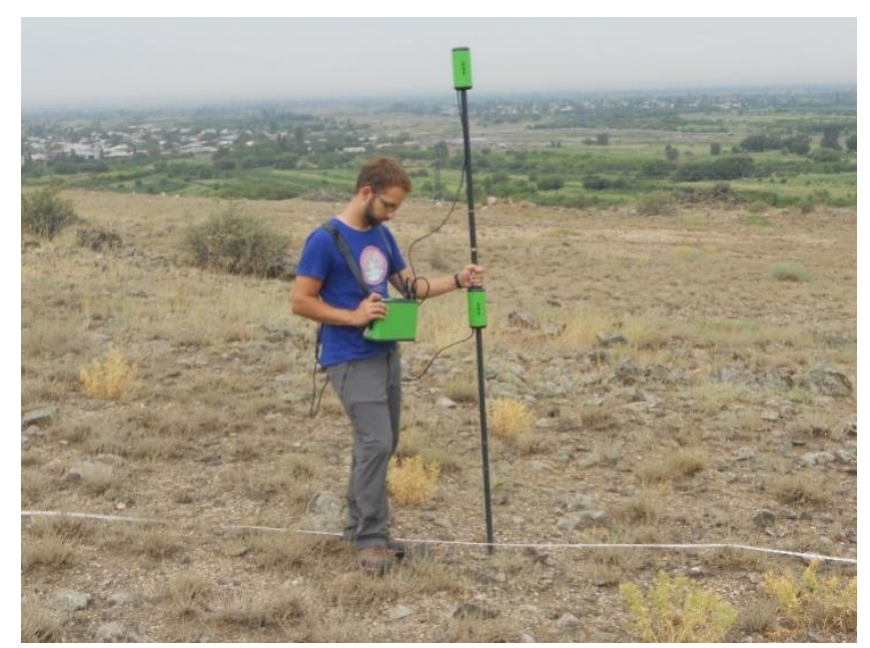

Figure 10. Armenia, Armavir province. PGM-1 gradient meter. 
The MXPDA system allows very dense measurement, works mainly in the grid of $20 \times 20 \mathrm{~cm}$. The measurements network of the PGM-1 was mainly $1 \times 1 \mathrm{~m}$.

\subsubsection{DEMP (Dipole Electromagnetic Profiling)}

The DEMP measurements were carried out via the CMD-MiniExplorer instrument by GF Instruments, measuring in one transmitting frequency on the three pairs of measuring coils (with their central spacings of $0.32,0.71$ and $1.18 \mathrm{~m}$ ). The results are in the form of frequency-dependent resistivity in ohmmeters in approximate depths that are based on the manufacturer's (GF Instruments testing base) calibrations and equal to $0.5,1$ and $1.8 \mathrm{~m}$.

Gained data were (after downloading) mainly displayed in the form of the 2D apparent resistivity and magnetic gradient maps. In several cases, the DEMP data had to be filtered, as the high resistivities of the volcanic rocks caused erroneous values due to collapse of the factory calibration and recalculation into the apparent resistivities.

The DEMP method was being routinely used at the Armenian sites (Figure 11). In Prague, this method was used at the Old Town Square and Hradčany Square.

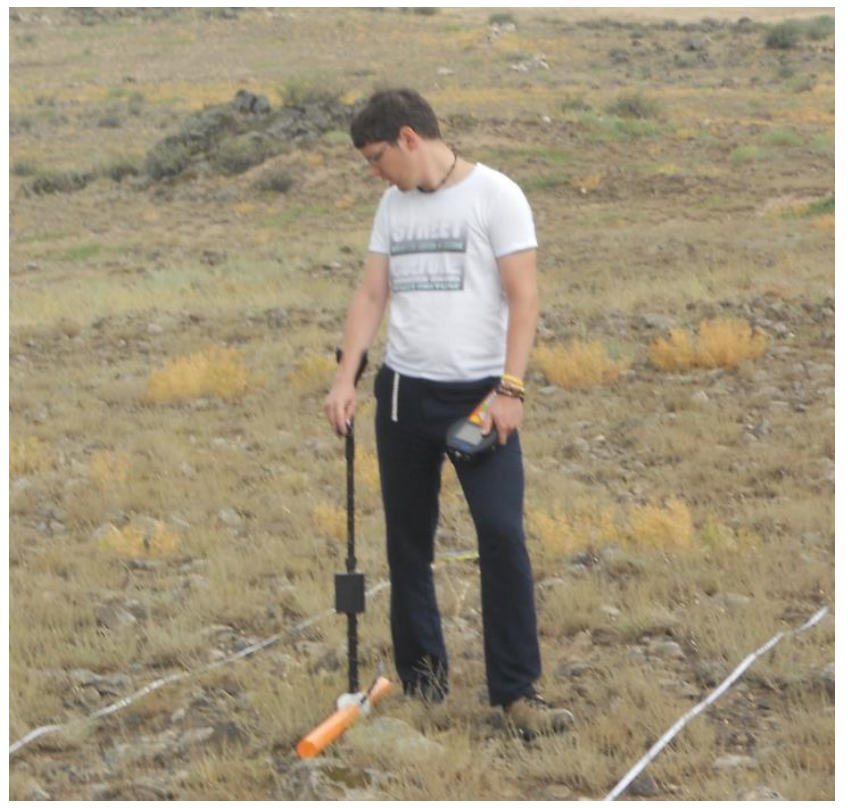

Figure 11. Armenia, Armavir province. CMD-MiniExplorer.

\subsubsection{GPR (Ground Penetrating Radar)}

The radar measurements were carried out via the SIR-20 (GSSI) instrument with 100- and 400-MHz antennas. The profile spacing was mainly $2.5 \mathrm{~m}$. The in-line scanning frequency was mainly $10 \mathrm{~cm}$. The quality of the records was controlled by an operator while measuring on the PC screen (Figure 12). Detailed data processing, their filtration, gaining, etc., was carried out afterwards in-office. 


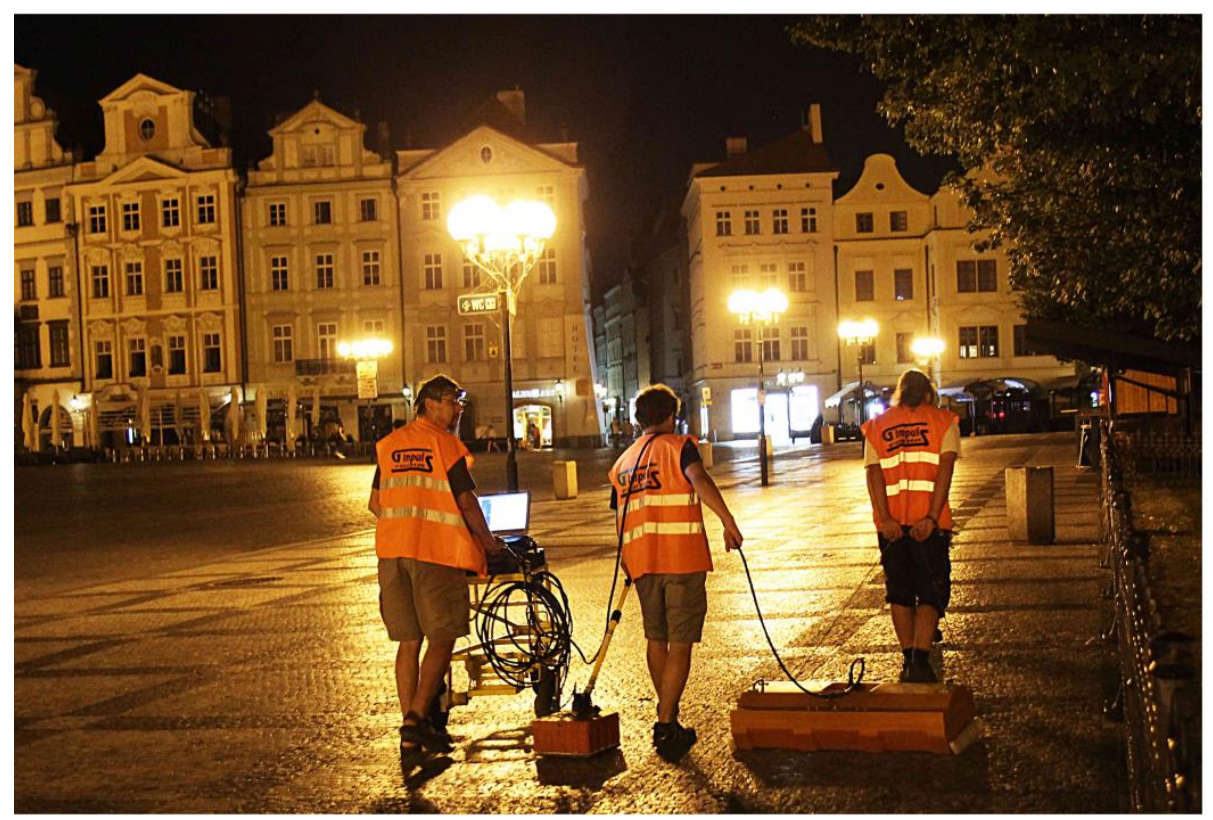

Figure 12. Old Town Square. Geological radar SIR 20 with 400- and 100-MHz antenna systems.

\subsubsection{ERT (Resistivity Tomography)}

For the ERT measurements the ARES II. instrument was used (GF Instruments, Brno, Czech Republic). Multielectrode measurements were mostly carried out using 48 electrodes; their spacing was mainly $2 \mathrm{~m}$. While measuring in the Prague downtown, we encountered issues with electrodes fixation in the cobblestones. This issue was solved by using thin electrodes placed into slits (Figure 13).

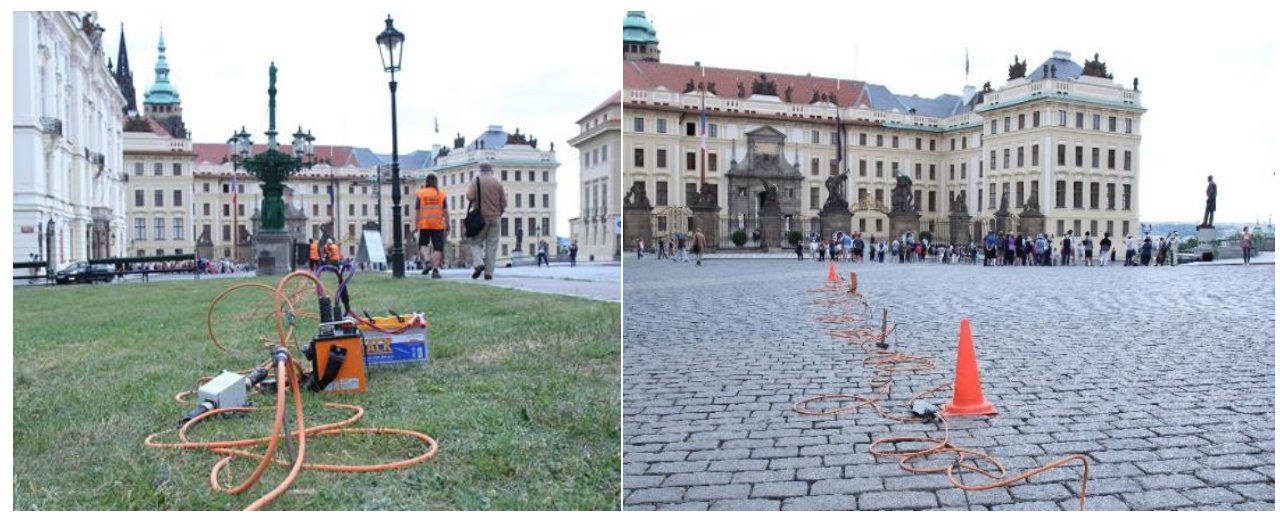

Figure 13. Hradčany Square. Geoelectrical system ARES II and electrodes on the profile.

\subsubsection{Gravimetry Surveying}

For the microgravimetric measurements, CG-5 and CG-6 (Scintrex) instruments were used (Figure 6). The prevailing spacing of the stations was $2 \mathrm{~m}$. The altitude of the gravimetric stations was measured by the total levelling station Leice Sprinter $150 \mathrm{M}$. The position of the gravimetric and other geophysical profiles was set by the GNSS receiver Trimble R8s (Figure 14). 


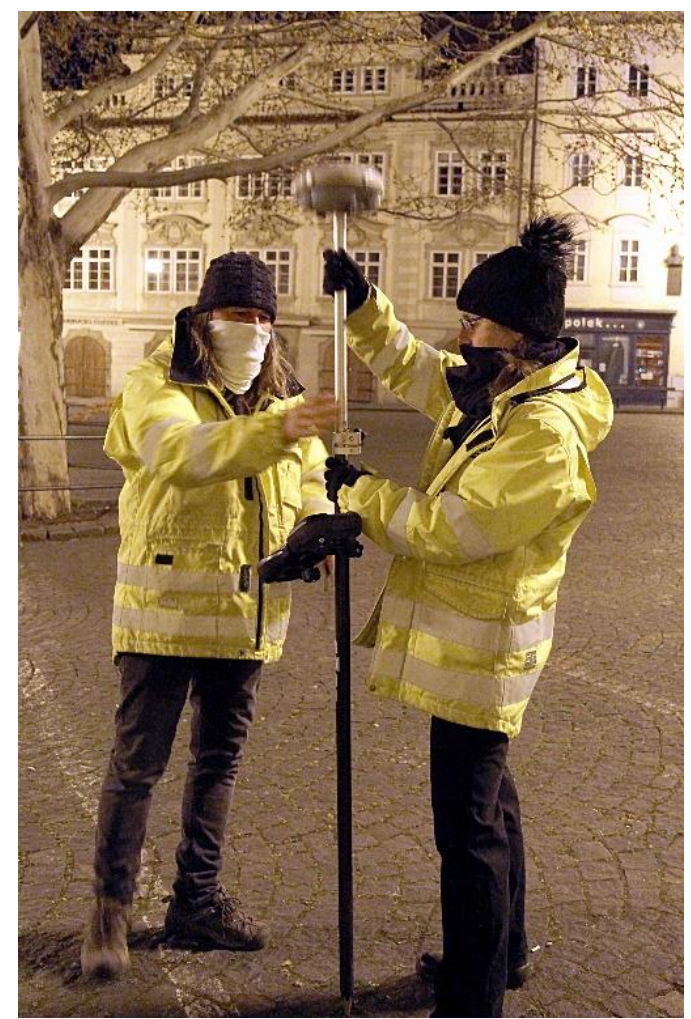

Figure 14. Trimble R8s at the Lesser Town Square in the times of coronavirus.

\subsubsection{Seismics}

For the seismic measurements, the Terraloc Mk-6 (Figure 15) and Terraloc Pro 248 channels instruments were used. The seismic shots were generated by the blows of a seismic hammer onto a plastic plate. The geophones spacing was mainly $2 \mathrm{~m}$. The seismic methods were used only at the Prague sites. Measured data were gained so they could have been transformed into the forms of seismic refraction, reflection and tomography. At the Old Town Square, a less used time-term method was used.

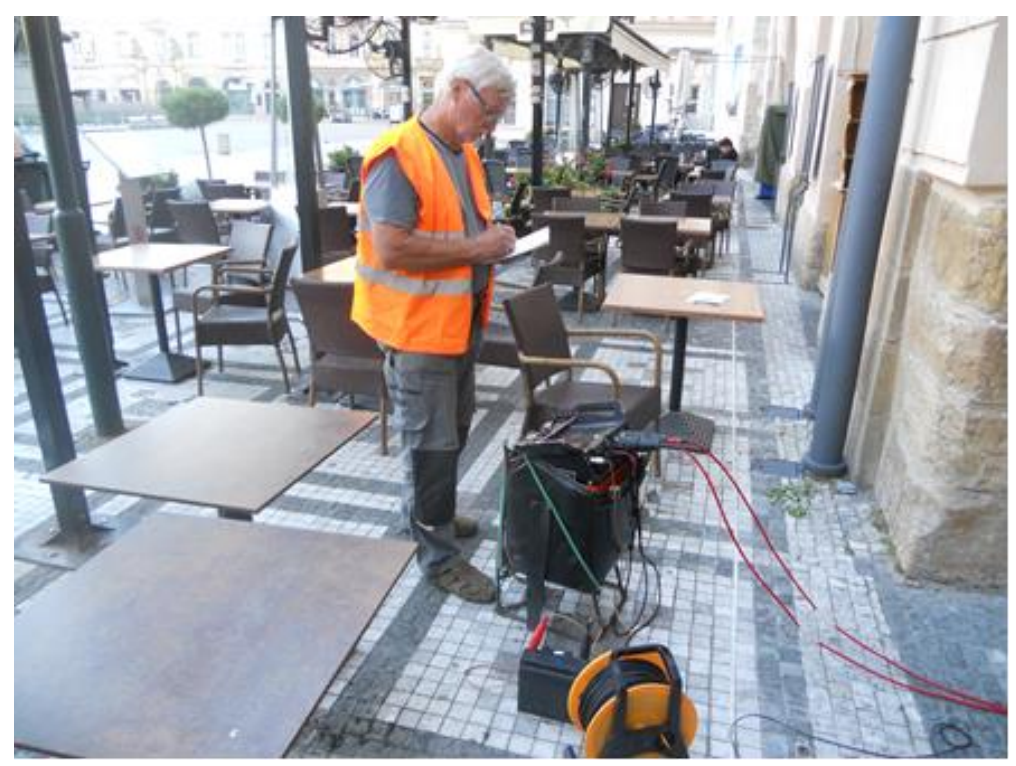

Figure 15. Seismic instrument Terraloc Mk-6 at the Old Town Square. 


\subsubsection{Data Processing}

For the data processing, the following software was used:

- Reflex W (seismic data processing);

- Rayfract 386 (seismic data processing);

- Radan (GPR);

- Res2DInv (resistivity tomography);

- Fast Grav (gravity data processing);

- Mag (gravity data processing);

- Geosoft (databases);

- Excel (databases);

- Voxler 4 (4D processing);

- Surfer 17 (3D pictures);

- Grapher 16 (2D and 3D graphs).

The abovementioned software can be found under their names on websites with a more detailed description of their features. An exception is the Mag program (gravity measurements), which is installed only on G IMPULS Prague computers.

During the data processing and the subsequent evaluation, a set of programs was used which has proven its qualities to our team for a long time. The Reflex W program enables the export of seismic data from the seismic instrument to a computer, when the format is changed to the Seg2 format, which is standardly used in seismic processing programs. After frequency analysis, filtration and adjustment of the gain of individual seismic traces, one can chose processing by the method of seismic reflection or refraction. Seismic data were measured in the field so that both basic processing methods could be used, i.e., reflection and refraction. The space between the individual seismic profiles was examined by the method of seismic tomography, i.e., seismic sensors were placed on one profile and seismic sources were excited on the adjacent profile. The program for seismic tomography is a part of the Reflex W software package, but for comparison you can also use the Rayfract 386 program, which works with slightly different velocity models. Experience shows that the Rayfract 386 program works very well for environments with a continuously increasing velocity gradient to depth. For tasks related to depths up to the first meters (which is typical for archeology), mainly waves with higher frequencies (up to hundreds of $\mathrm{Hz}$ ) were used and mainly transverse waves were monitored.

The Reflex W program was also used to process radar records, because radar waves have essentially similar behavior to seismic waves; the change is only in the frequency and velocity of wave propagation. Simultaneously with the interpretation using the Reflex program, the radar records were also processed using the Radan 6 radar program. The implementation outputs from both programs were roughly identical.

The program Res2Dinv was used for resistivity measurements. It is a set of processing and interpretation programs focused mainly on multielectrode measurements, which are evaluated in the form of resistivity tomography (ERT). The final output is resistivity cross-sections compiled from the values of the interpreted actual resistivities. In practice, however, it is necessary to realize that the interpretation of real resistivities is always, to some extent, influenced by our initial concept of the structure of the studied environment. Hence, the resistivity cross-sections are models whose reliability is affected by the operator's experience and basic knowledge of the composition of the investigated environment and its physical properties. In some cases, it is possible to prefer sections composed of directly measured data (apparent resistivities) that are not affected by a subjective approach to interpretation. 
For dipole electromagnetic profiling, a program supplied by the instrument manufacturer (GF Instruments, Brno, Czech Republic) was used for processing. GF Instruments' devices are calibrated at the company's test base, and thus the depth ranges of penetration of electromagnetic waves into the rock environment and their behavior in a layered or otherwise arranged environment are also tested by field practice. This is important because the reliability of laboratory model tests or theoretical calculations have their limits in electromagnetic fields.

For gravity measurements, the Mag evaluation program was preferably used, as it enables the creation of both layered gravity models and monitoring of the influence of spatially limited formations (sphere, cone, etc.). This program was created in the DOS environment and is, therefore, being gradually replaced by the Fast Grav program, which is fully compatible with the Windows 10 environment.

Programs of the Golden Software series (Grapher, Surfer, Voxler) were used for graphic processing. The Oasis Montaje program (Geosoft) was used to manage large volumes of data.

\subsection{Project Management}

Sites in Prague were measured via a wide spectrum of methods. Geophysical campaign was carried out by a team of approximately seven persons which allowed simultaneous measuring using several methods. The work shift was mainly in the nighttime with less traffic going on on-site. In several cases, the measurements were assisted by the municipal police stopping the traffic completely. After each shift, the measured data were downloaded off the instruments and primarily checked. After the data were uploaded into the office server, the data processing and evaluation could have started. Entire raw data and other outputs are archived and are permanently available for the needs of authorized users. Each particular project (site) has its own concluding report. The report represents current assignments of the contractor and its actual needs. However, the way of archiving the measured data and their processing allows consequent use of the results reinterpretation in the later stages so the results can be updated upon new requests of the database's users.

Different approach was chosen for the Armenia expeditions. Limited budgets of the international expeditions, declare limitations, etc., would not allow the use of wider complex of geophysical methods in the initial projects. The used methods were mainly magnetometry and DEMP. With respect to favorable geological and physical properties (volcanic rocks on the sites), even the limited methodology brought necessary findings for further development of the works. For each field day, a schedule of geophysical works was planned according to the time constraints and field conditions. Every evening after finishing the field works, the data were downloaded and primarily processed. After discussion on the preliminary results, the work plan for the next days was made. Final data processing and reporting were finished after coming back to the Czech Republic.

\section{Results}

\subsection{Charles Square}

In the central part of the Charles Square, the spatial GPR survey, seismic refraction measurement, ERT and gravimetry were carried out. The complex of methods allowed to roughly map out zones with remains of the chapel and graveyard which were partly proved by the sounding works (Figure 16).

From a methodological point of view, we found that the ERT method is able to detect Middle Age burial areas as the graves with the mortal remains manifest as smaller objects of low resistivity (Figure 17). After excavation of the tomb, this fact was explained as the influence of decomposed soft tissues of a body (organic material has low resistivity). 
The results of measurements at the Charles Square could be verified by a limited archaeological survey (Podliska [17]). The location of the masonry of the defunct chapel was confirmed, as well as the identification of graves detected geophysically (Figure 18). The preparation of a pedestrian underpass in this place was stopped.

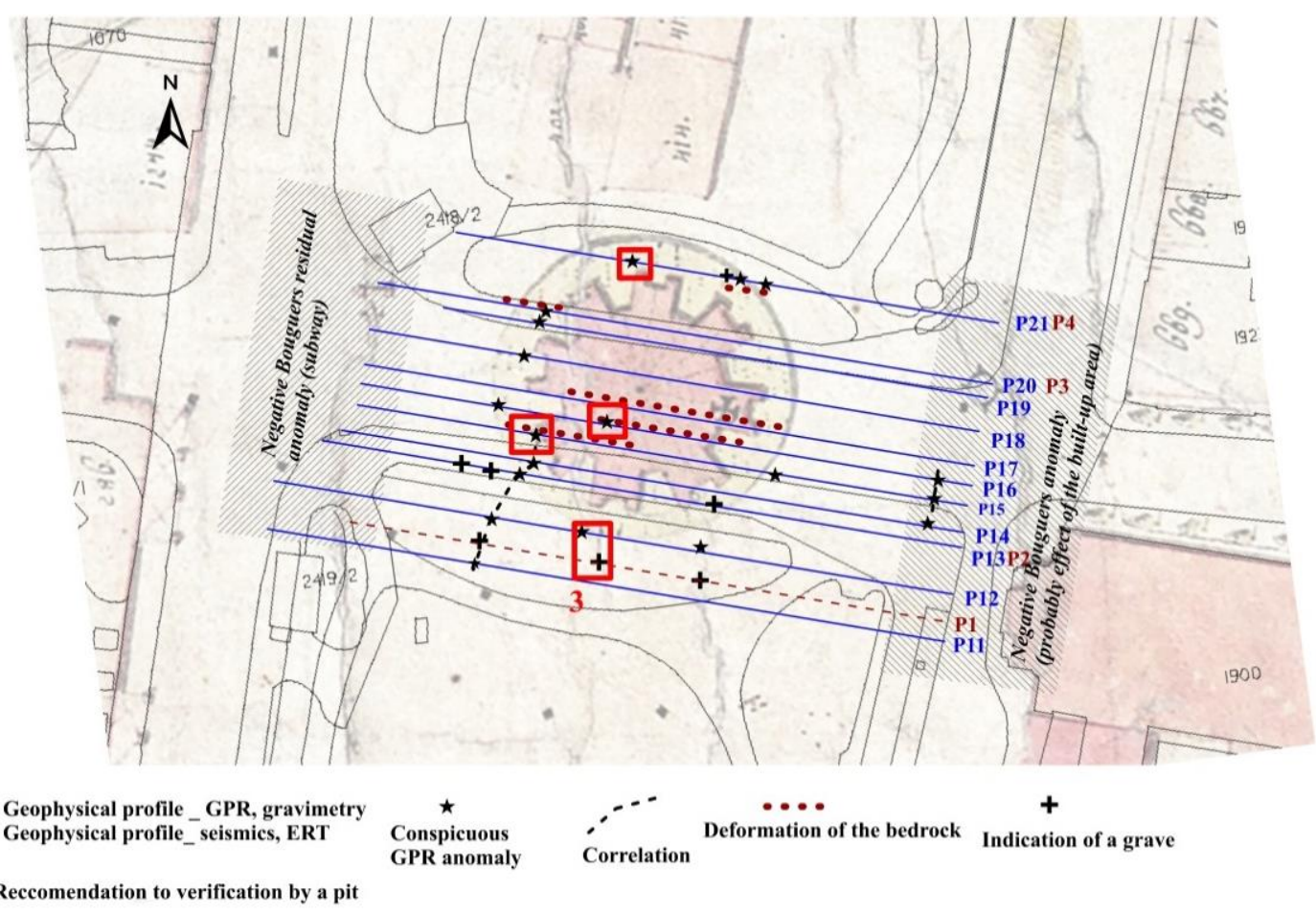

Figure 16. Charles Square. The archival map with the foundation of the chapel (Helgert, 19th Century) with principal geophysical anomalies indicating single graves or tombs. Archaeological test pits are marked in red.

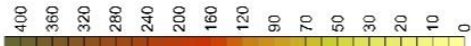

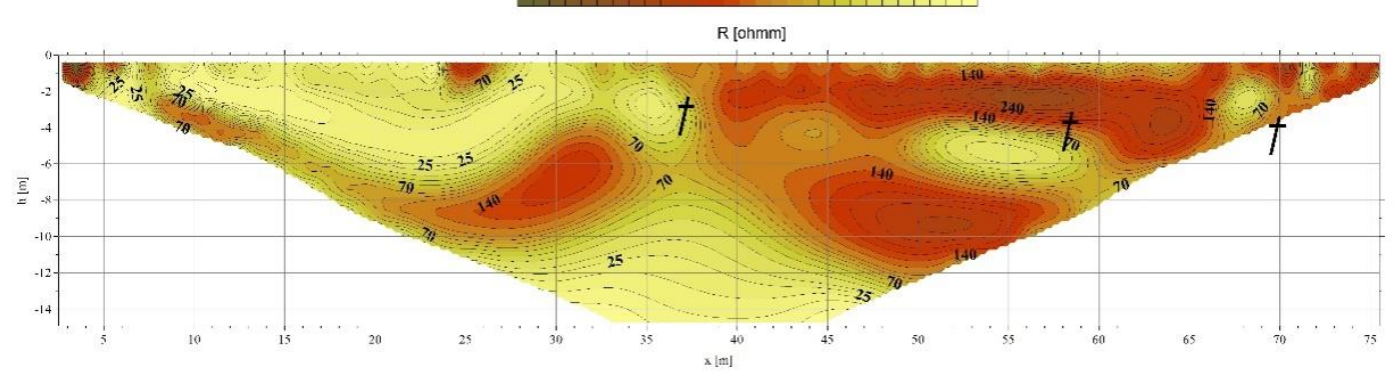

Figure 17. Charles Square. The resistivity cross-section (ERT) with indications of the graves (see small crosses). 


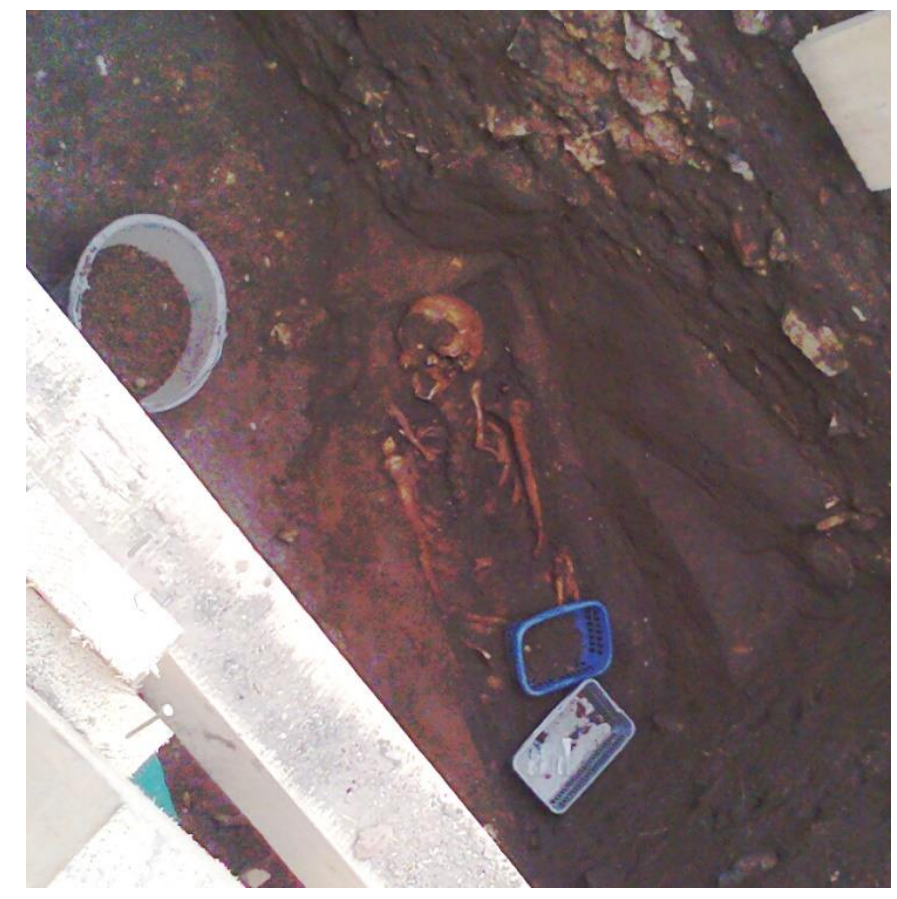

Figure 18. Charles Square. Grave with skeleton which was detected by ERT.

\subsection{Old Town Square}

Within the Old Town Square area, a detailed survey was carried out, covering not only the square itself but aimed also to the area of expected remains of burned down gothic revival town hall wing (a consequence of World War II). From a methodological point of view, we would like to stress an experiment with measured magnetometric data. Our experiment was partly inspired by a common way of micro gravimetry data processing when the regional field is subtracted from the Bouguer anomalies. For the interpretation, we then get the residual anomalies, locally limited, which can be considered as caused by local objects close to the surface. Figure 19 shows the unprocessed measured data of the vertical magnetic gradient in 3D and 2D. Figure 20 shows the map of magnetic values made by extraction of the values between + and -100 gama. The map expresses low values of the gradient by green color, the other areas remain white. This way of displaying allows some sort of structures or directions (blue lines) to be followed, which cannot be explained as known objects (sewage, cables, light poles, etc.).The determined values will be the subject of archaeological research in the future, which is organizationally and technically demanding due to the intensive traffic in this public area.

Measured magnetic field is going to be further investigated via techniques of spatial analysis, which is traditionally being used for the aerial geophysical data processing. 

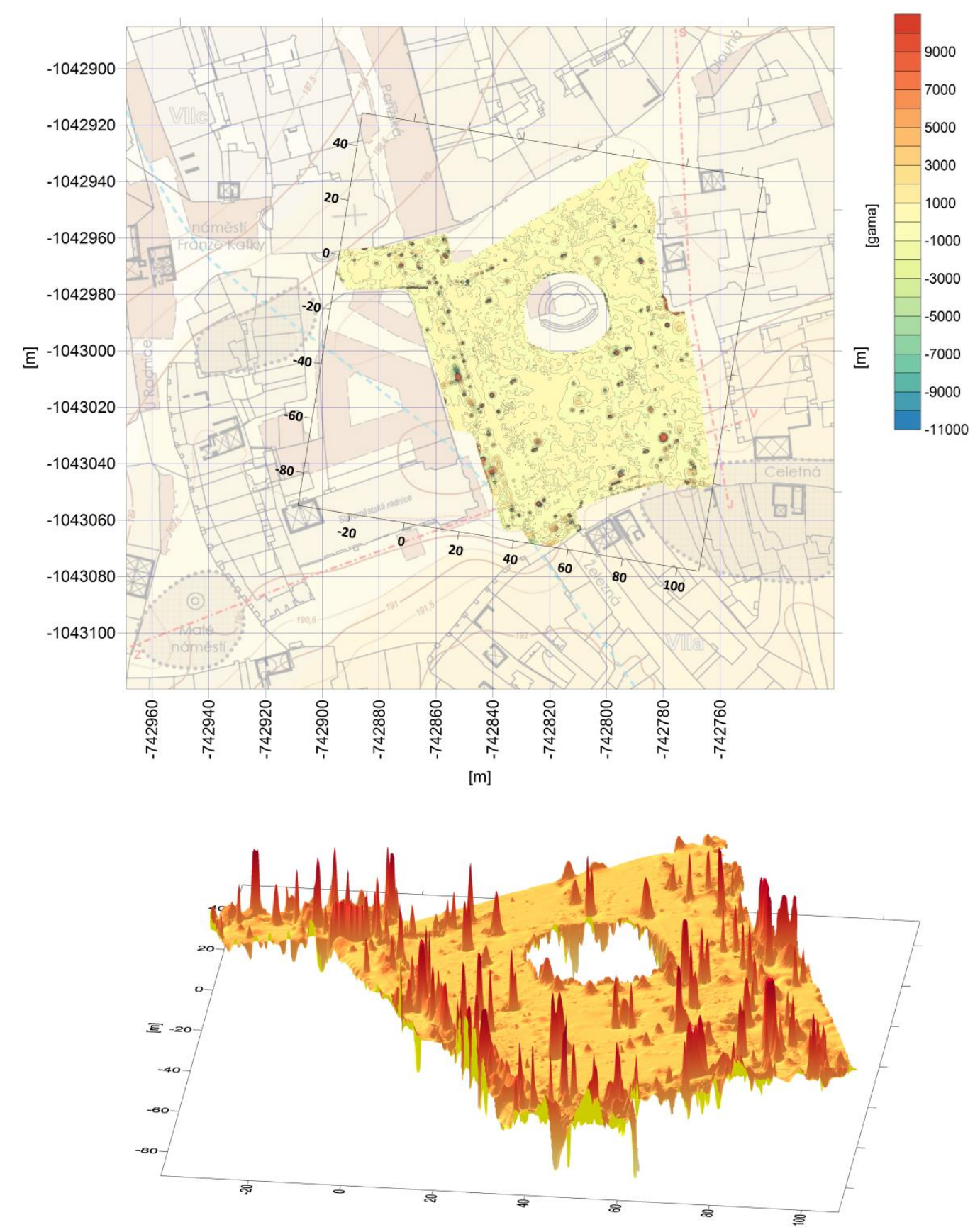

Figure 19. Old Town Square. 2D (above) and 3D (bottom) images of the vertical gradient magnetic field in the unprocessed measured data. 


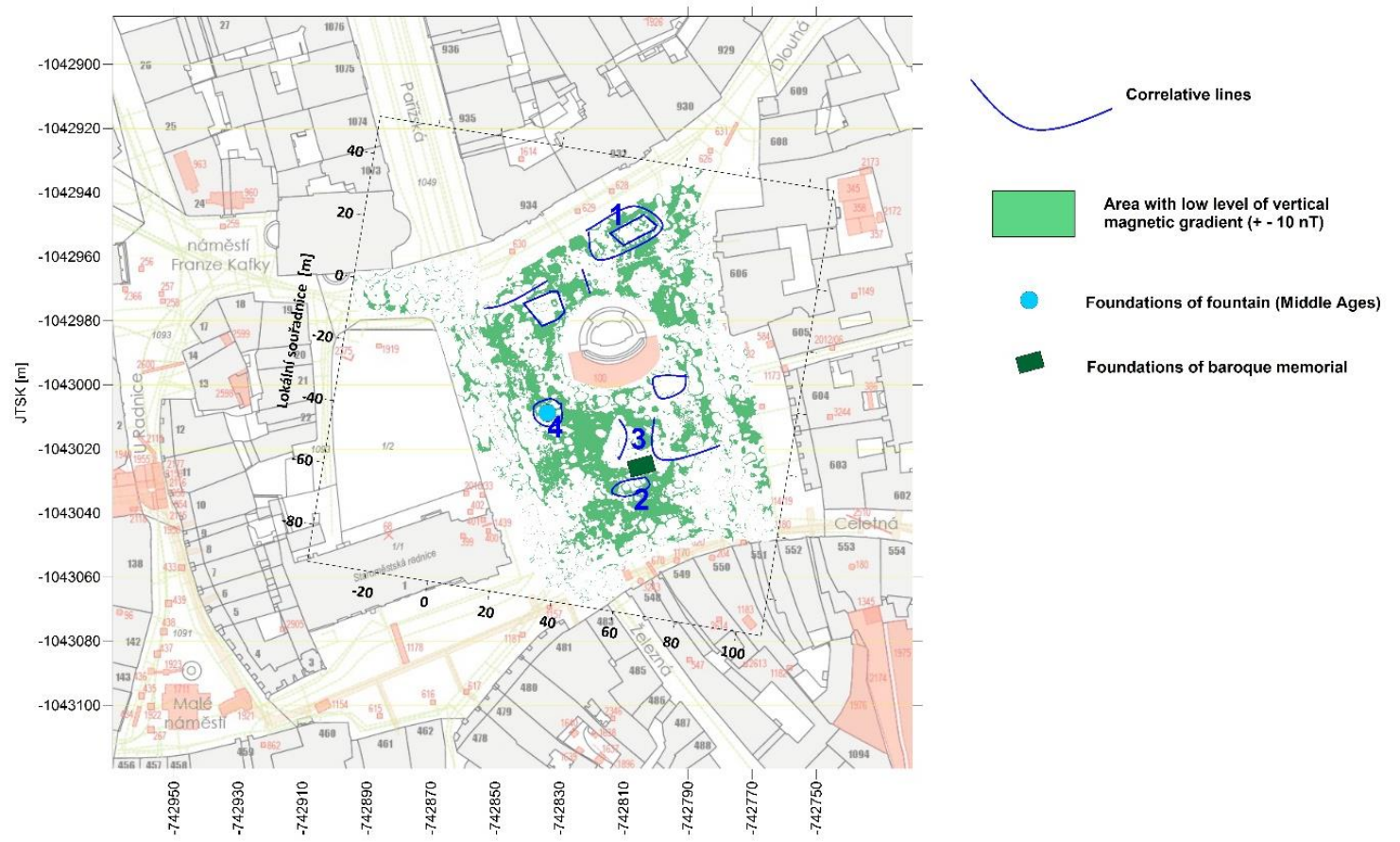

Figure 20. Old Town Square. The map of areas with low intensity values ( \pm 100 gamma). Low values of the gradient are marked by green color, the other areas remain white. 1 -Structure is probably an indication of so-far undiscovered marketplace; 2,3 and 4 are probably traces of the activities around the defunct fountain (4) and Maria memorial $(2,3)$.

\subsection{Hradčany Square}

The non-destructive geophysical survey aimed to cover a whole area (if possible) of the square and according to the complex geophysical methodology to describe in detail the bedrock's state of manner and to try to define and localize any archaeological structures' indications. The Hradčany square has not been exposed to any construction or research activities in present days. Excluding the rescuing archaeological 1944 survey in the central part no significant spatial outcrops have been made, only the linear trenches' documentation of the engineering networks. The chosen methodology aimed mainly to identify assumed north-south medieval trenches going across the square.

We used a set of geophysical methods as follows:

- Spatial magnetometry;

- $\quad$ Spatial geological radar (GPR);

- Spatial dipole electromagnetic profiling (DEMP);

- Profile gravimetry;

- Profile complex seismics;

- Profile resistivity tomography (ERT).

The medieval trenches were detected by several geophysical methods (DEMP, gravimetry, not so much strongly seismic measurements and ERT). In Figure 20, the map of the area of interest with isolines of conductivity is shown (result of the dipole electromagnetic profiling) with interpretation of the medieval trenches. Figure 21 shows profiles where gravity measurement was carried out. In Figure 22, the graphs of Bouguer (gravity) anomalies are presented together with the interpretation of medieval trenches (ditches). 


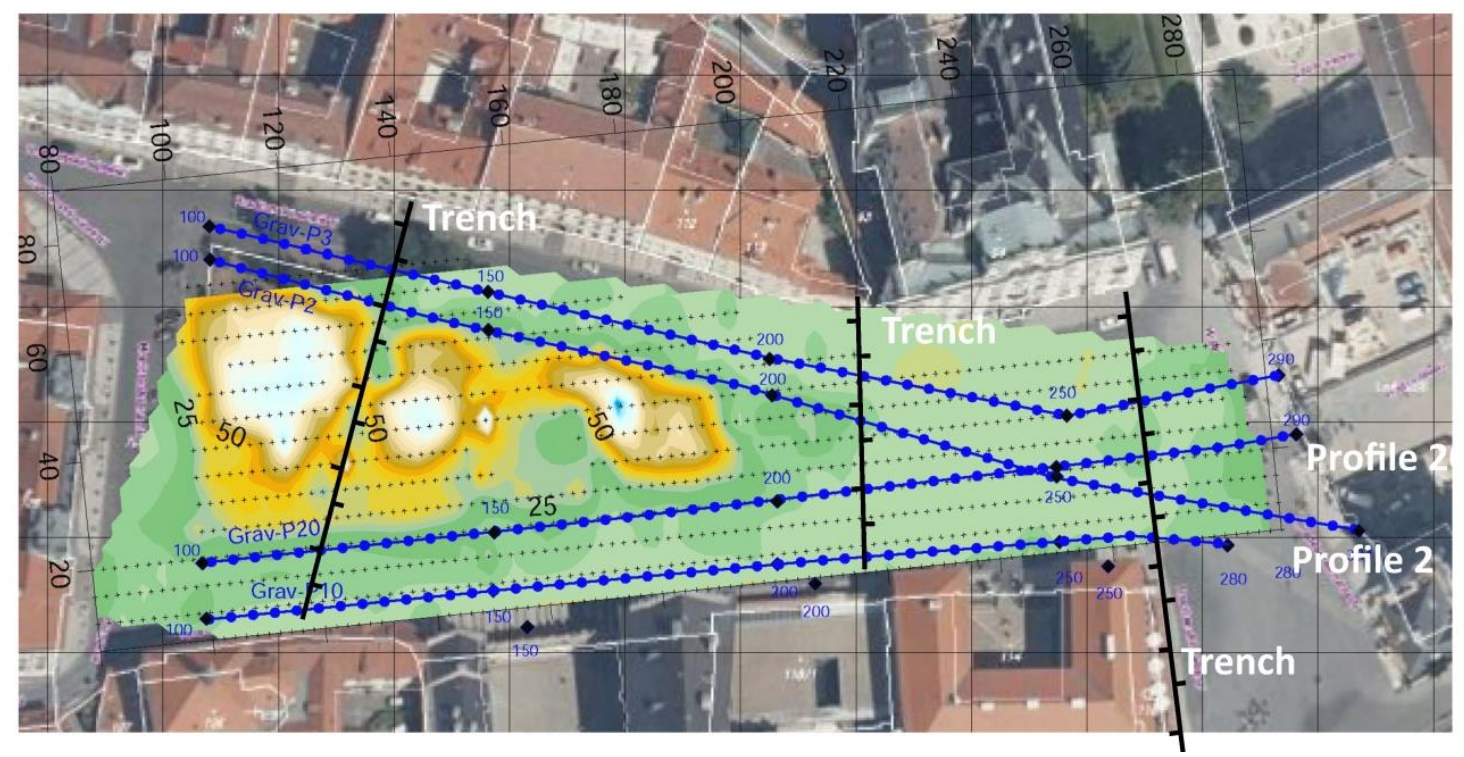

Figure 21. Hradčany Square. The map with isolines of conductivity (by DEMP), gravity profiles and interpretation of the medieval trenches.
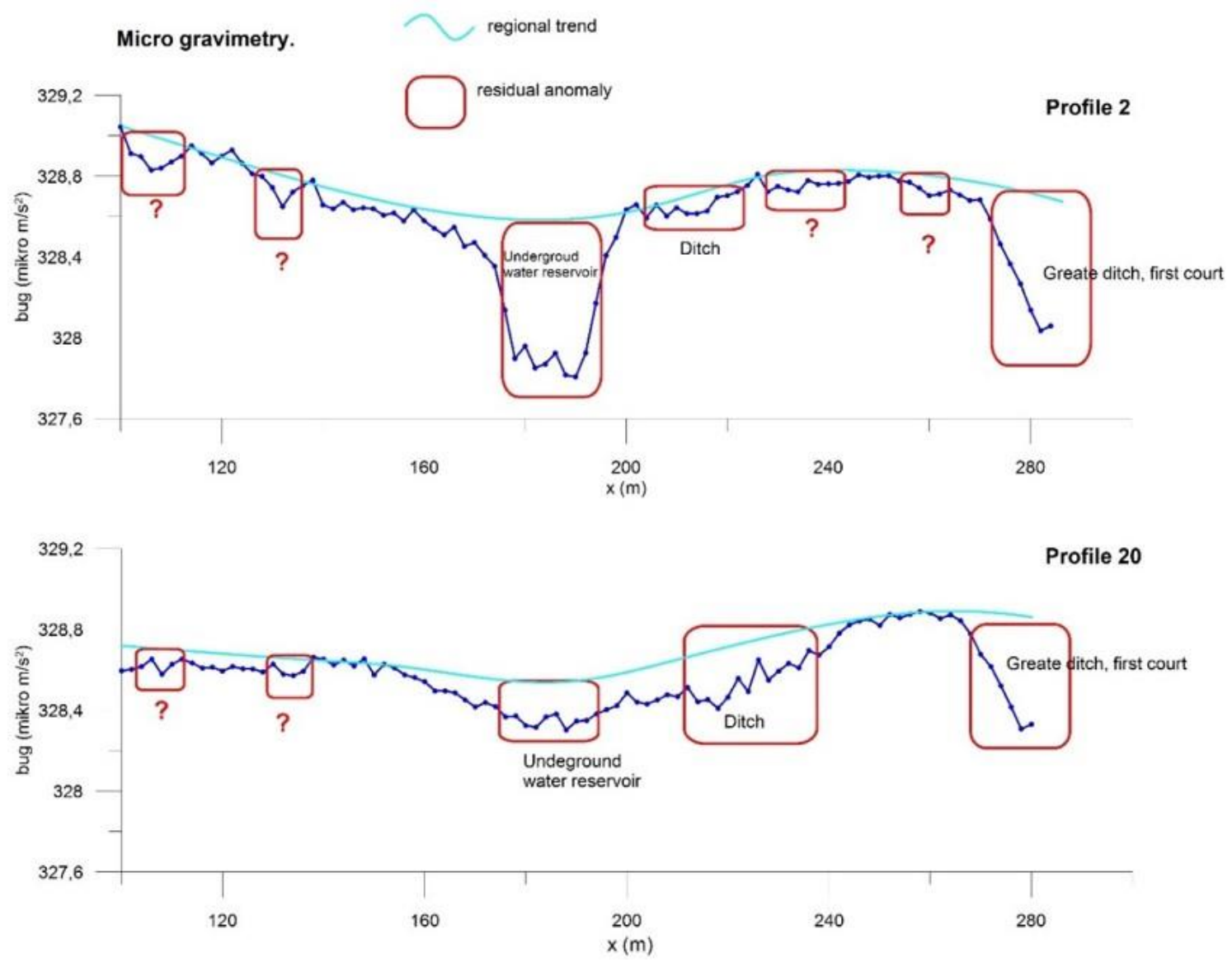

Figure 22. Hradčany Square. Graphs of residual Bouguer anomalies. Profiles in direction W-E. 
Frequent objects of varying ages were detected at the Hradčany Square. What surprised us was the detection of the underground water reservoir which lies in place of the old removed fire reservoir of World War II. This new reservoir had to be built-up secretly during the Cold War, as there is no existing documentation about the object. The reservoir is clearly visible on the GPR results and as a small negative gravity anomaly (Figure 23).
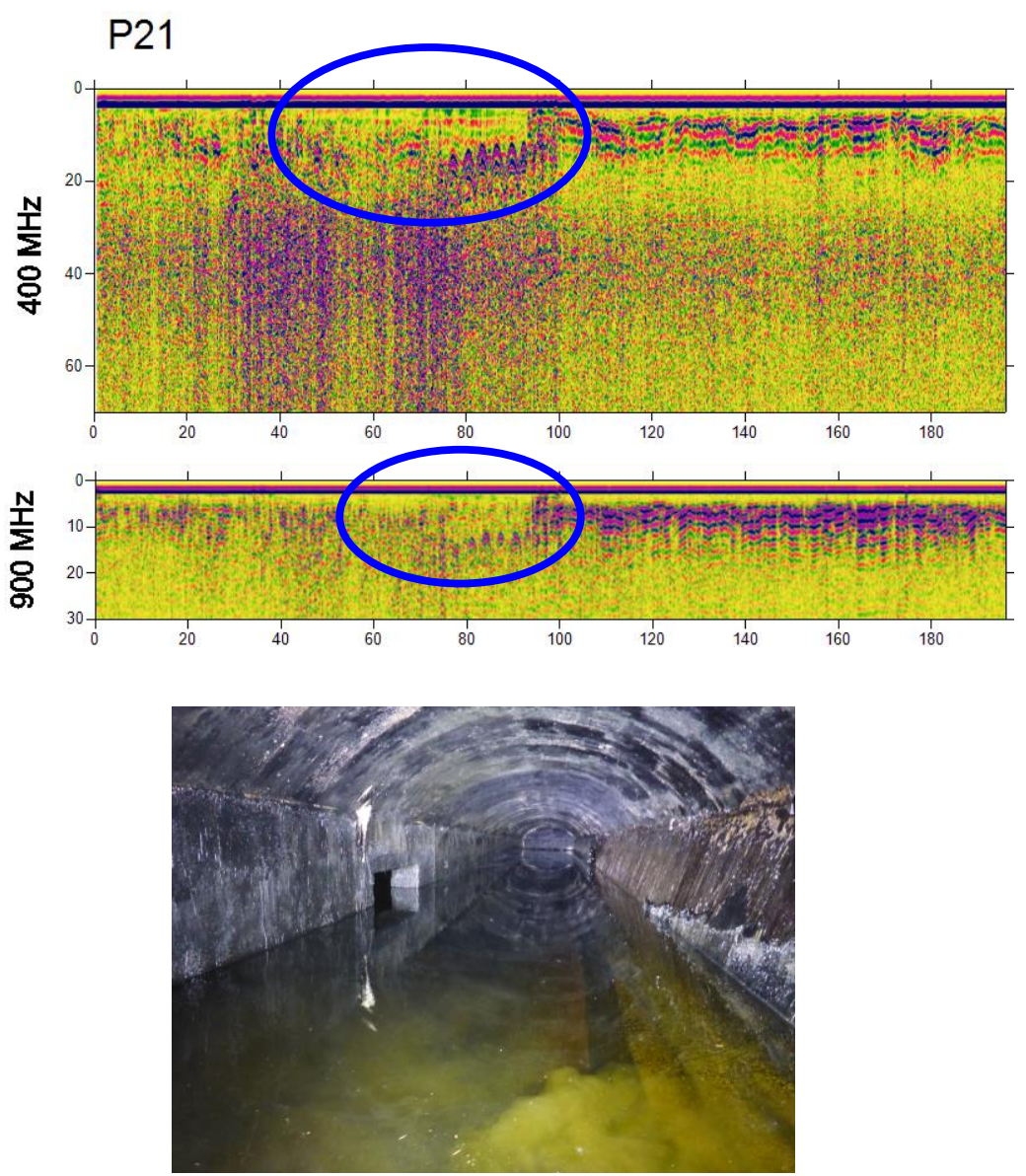

Figure 23. Hradčany Square. GPR anomalies above the underground reservoir.

The data processing and preliminary interpretation of the magnetic measurement is shown in Figure 24. We start with original vertical gradients of the field data. The primal data are transformed into a regional field, i.e., the data are smoothed out by a coarser grid (see for example software Surfer). The final analysis uses residual anomalies, i.e., a difference between measured data and regional data. 

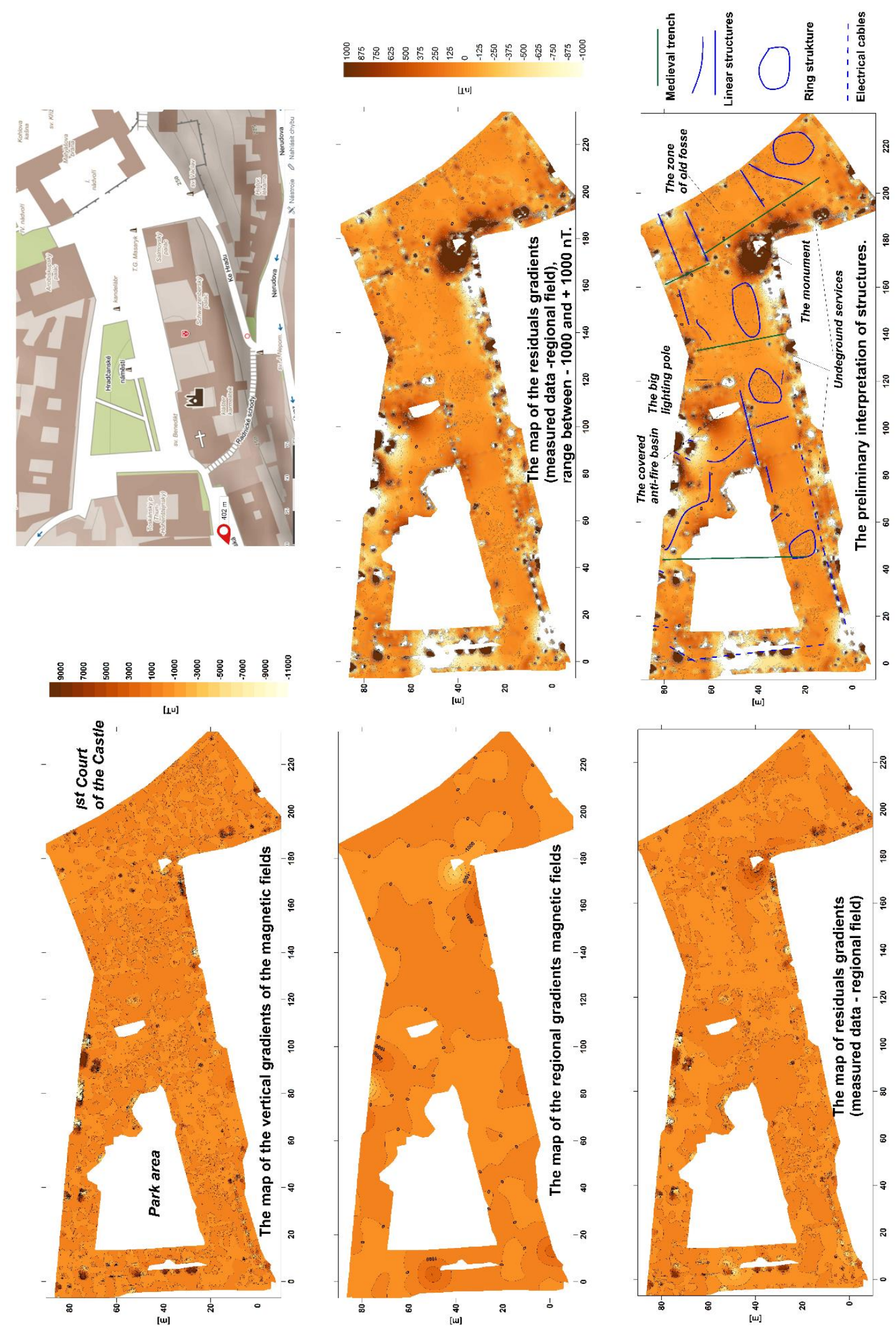

Figure 24. Hračany Square. The analysis of the magnetic measurements and preliminary interpretation. 


\subsection{Lesser Town Square}

At the Lesser Town Square, the contracting authority emphasized that the task of the measurement is not only to discover clues that will be of interest to archaeologists, but that it is important to obtain a summary of information that will also be used to plan the upcoming revitalization of the square. When revitalizing the square, it is necessary to avoid objects that could be damaged by heavy mechanization and excavation work. For this reason, a comprehensive map of significant geophysical anomalies was compiled (Figure 25). These places should not be disturbed by deeper excavation work. Furthermore, the map contains hatched places where we expect a consolidated environment in the first meters in depth. In these places, it is possible to store building material or park with construction mechanisms.

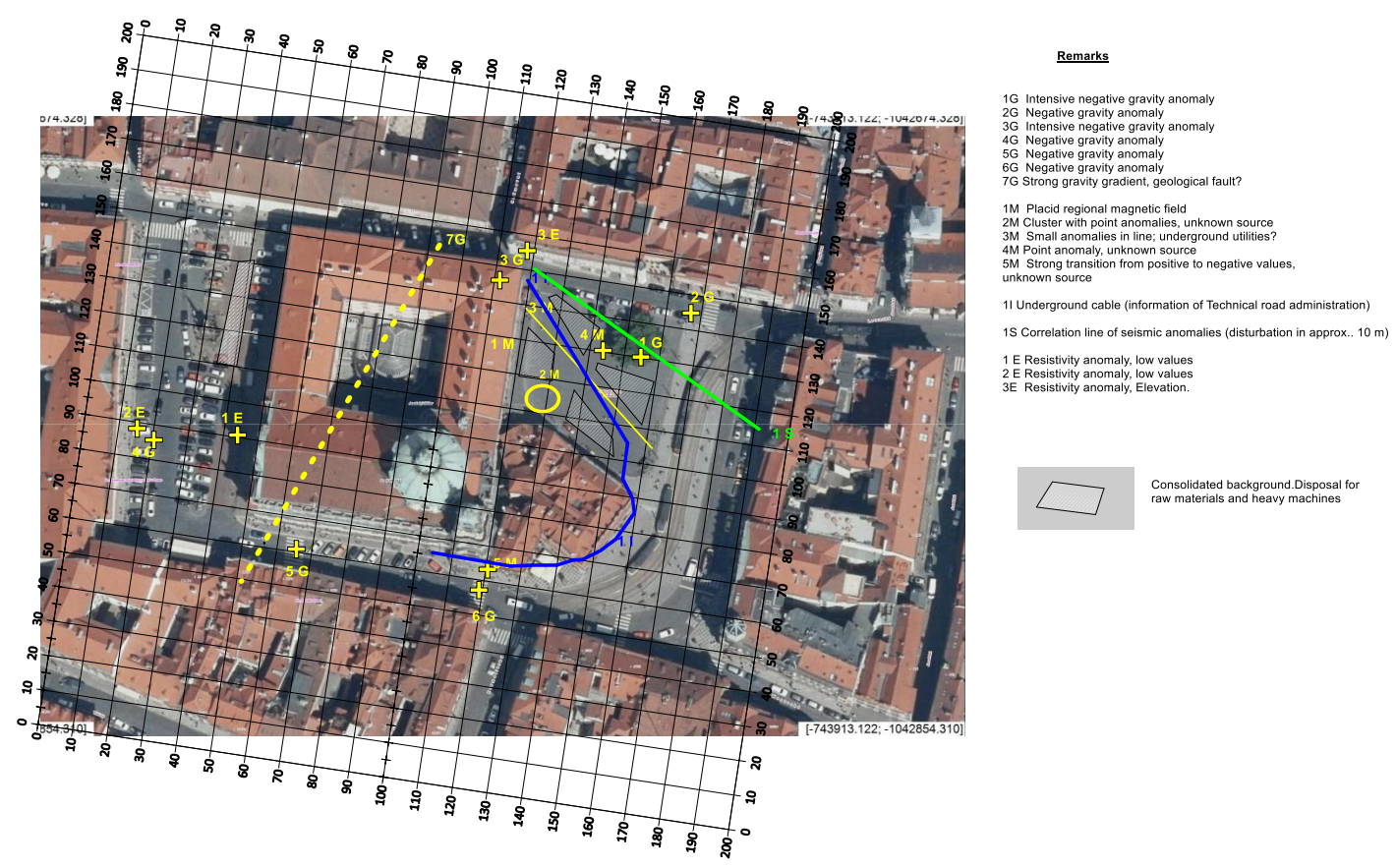

Figure 25. Lesser Town Square. Summary of geophysical results and anomalies. G-gravity, $\mathrm{M}$-magnetometry, E—resistivity, I—underground utility.

Figure 26 shows the radargrams, seismograms and resistivity cross-section on the profile P155. The profile ran in the S-N direction and lies in the eastern part of the square (the profiles are numbered according to the local network, see Figure 25). A red ellipsis in Figure 26 shows correlated anomalies manifested via all methods. This probably equals to a disrupted area after the excavation works. Similarly, one can observe other anomalies, too. 

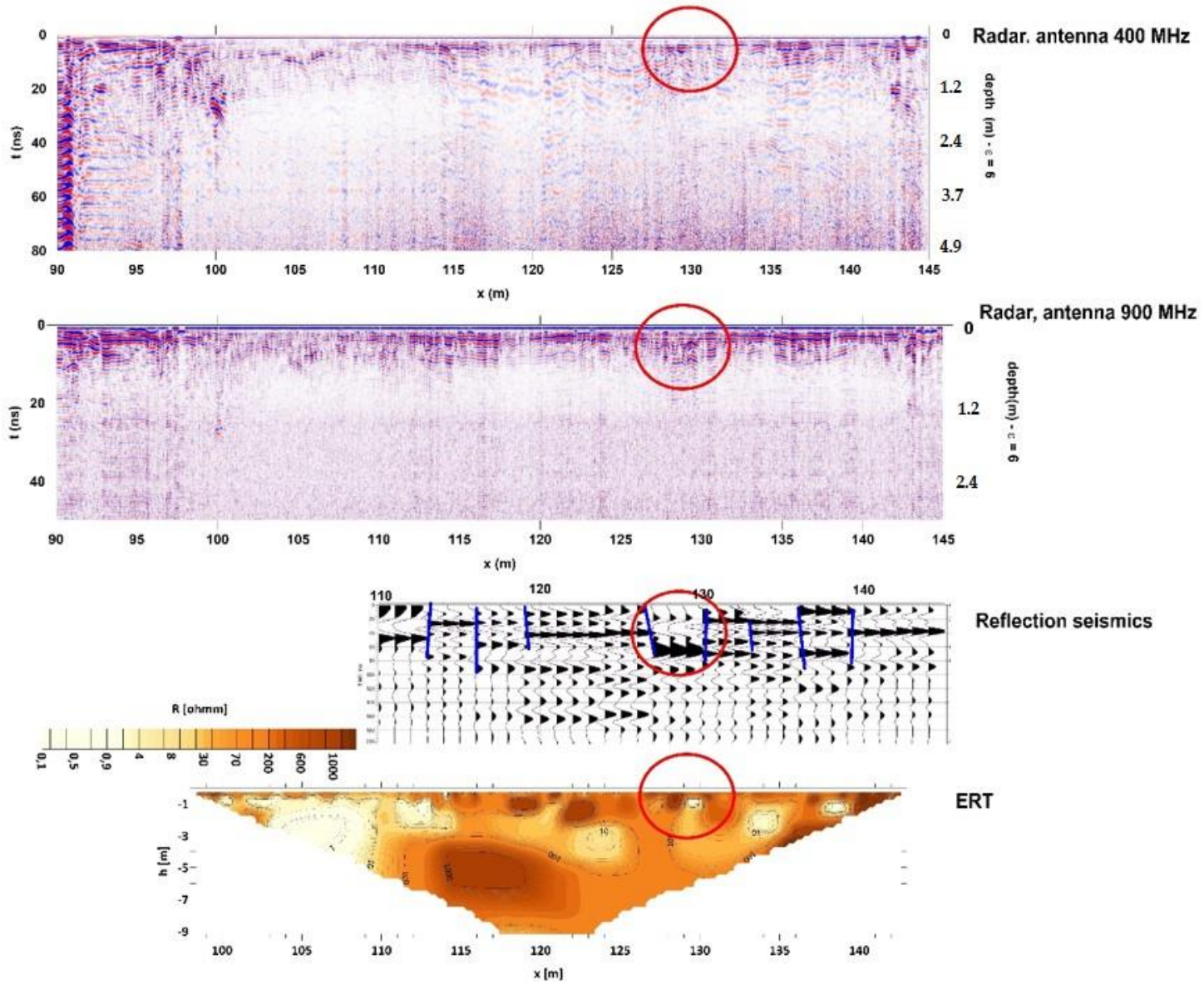

Figure 26. Lesser Town Square. Summary of geophysical methods-ERT, seismic reflection and radar on the profile P155.

\subsection{Armenia Sites}

During three expeditions, about 10 sites were visited and measured. Almost all sites were characterized by the fact that the foundations of buildings and other archaeologically interesting objects were built of volcanic rock with increased magnetic susceptibility. On the contrary, the fillings of graves or mounds were made of very fine-grained soils with high conductivity. For this reason, it was possible to successfully use the magnetometric method and the DEMP (Dipole Electromagnetic profiling) method for the reconnaissance phase of the work. For the detailed stages of the survey, we plan a wider complex of geophysical measurements, which, however, requires more demanding organizational preparation and financial security.

\subsubsection{Ghanjyan Blur Site}

Ghanjyan Blur site consists of the stone objects relics (shapes of medieval houses or prehistoric graves) covered by remarkably thick overlying sediments. The goal of the measurements here was to map out archaeological features and possibly guess on the thickness of the sediments. Together with geophysical measurements, a detailed sketch and sherd analysis of the site was carried out. We proved existing larger archaeological objects and detected right-angled structures (probably walls—Figure 27). 
DEMP

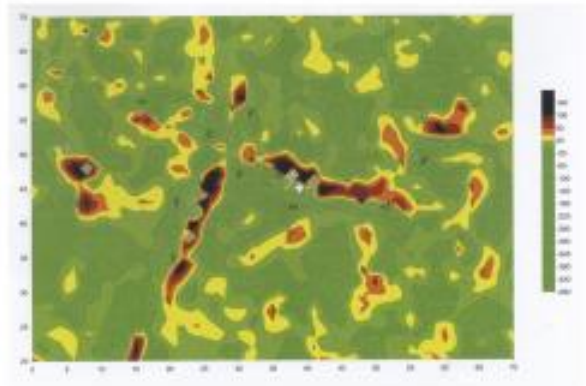

Magnetometry

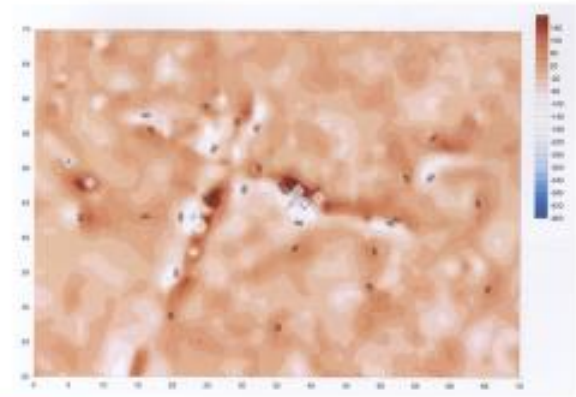

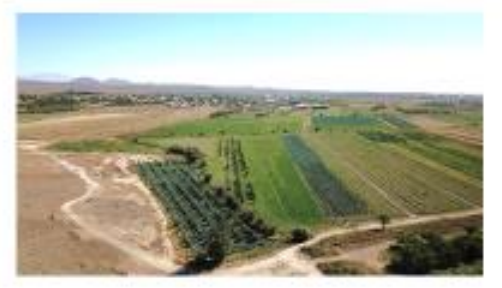

Figure 27. Ghanjyan Blur. Example of the detailed measurement with indication of two 2D structures (possibly walls).

\subsubsection{Lernamerdz Site}

Thus far, the site is not researched sufficiently. However, the outcrops clearly show primitive figures from the prehistoric era (Figure 28). Figure 29 shows the geophysical field measurements on-site.
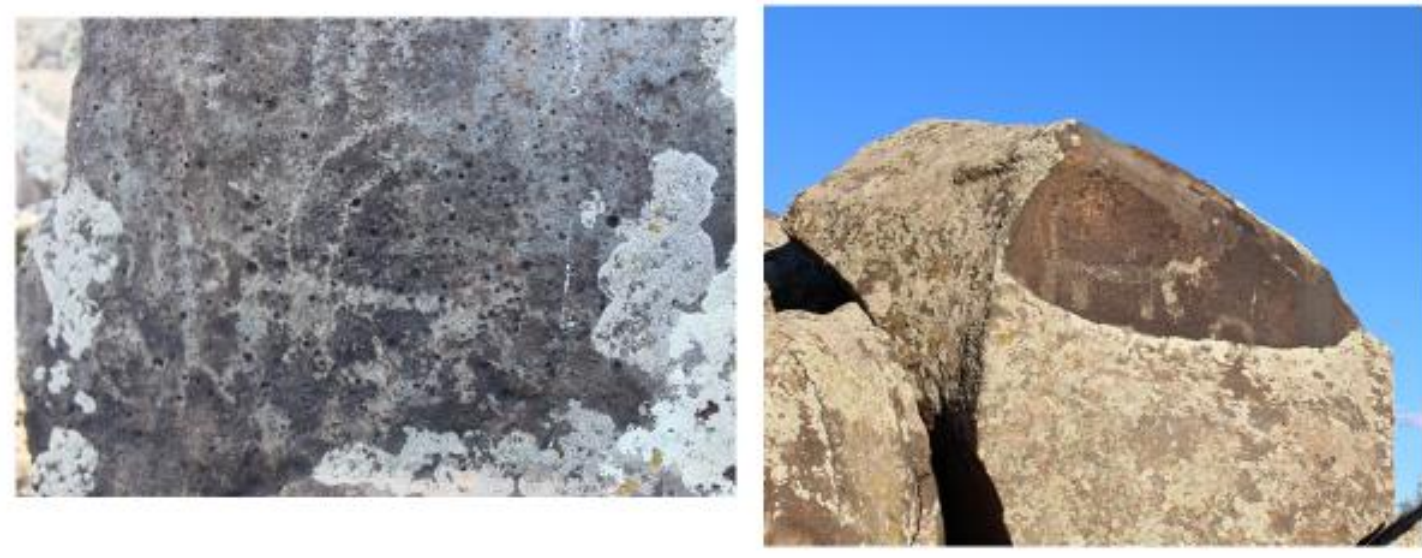

Figure 28. Lernamerdz. Manifestation of prehistorical activities.
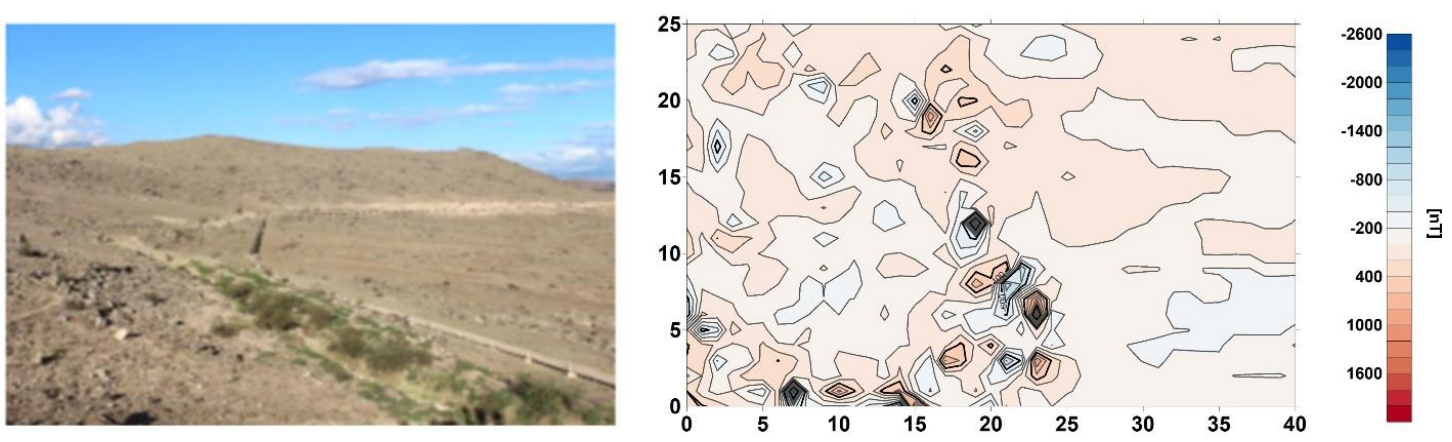

Figure 29. Depiction of magnetic gradients registered at the Lernamerdz archaeological site. 


\section{Discussion}

Most geophysical works for archaeology, as we can see in the literature, focus on one small place of interest in order to specify the presence of objects whose physical properties can be assumed. The use of magnetometry prevails; the results were slightly less accurate using the GPR (geological radar). Successful measurements usually come from places where the work is not disturbed by the presence of engineering networks, stray currents, modern buildings, etc. From the literature and the authors' own practice, it can be pointed out that geophysics is a valid help for archaeologists should the user of results asks right questions and presents a valid concept of the site of interest. For example, in Hrubec [27], an example of finding medieval marl walls is described. The geophysicist logically assumed that such objects were in the place of interest and mistakenly considered marl blocks of natural bedrock to be such objects. Geophysics monitors the physical properties of the environment and usually cannot comment on the historical age of the detected object. Budinský [28] provides an example that draws attention to changes in the physical properties of some rocks due to climate. Claystones, which seemed to be very solid and were characterized by high seismic velocities, became slurry due to wetting, and the originally measured high-velocity anomalies were no longer measurable.

The examples presented here bring findings from research where geophysics is used less or is accepted with distrust. Measurements in paved squares and in places used for car and tram transport are very difficult for geophysical work. On the other hand, knowledge from such places provides information that can be used by archaeologists, historians, as well as experts preparing sensitive revitalizations of historic sites. The assignment of works, which we solved for the Prague urban area, represented the first phase of the work. By consistent and comprehensive measurement of the entire areas of interest, databases of direct geophysical data were obtained, which underwent initial data processing and the first interpretation. Our findings have mostly led to the fact that the density of information (geophysical anomalies) in areas of interest is considerable and their accurate qualitative interpretation is often possible only after a detailed discussion with other specialists. Thus, it is a teamwork-based activity in which archaeologists, historians, civil engineers can, in cooperation with geophysicists, use the measured geophysical database in future years (including reinterpretation of data, detailed geophysical surveys, etc.). Our work has shown that geophysical measurements in urban areas are possible with the right methodology.

The experience of working in Armenia is contrasted in the present article. It is a measurement in natural, sparsely built-up terrain and, at the same time, under conditions of work with limited financial and material equipment. Work in Armenia provided the first experience that can be used for larger expeditions. On the basis of the good results using magnetometry and electromagnetic methods it is necessary to appeal for further research of this type as Armenia is very rich in historical monuments. In addition, it was the first measurement in Armenia at archaeological sites interpreted for prehistory and the Middle Ages as village settlements. Thus far, countless measurements have focused on prehistoric fortified sites. However, in addition to tourist attractions, these sites are threatened by unprofessional collection of historical artifacts and are also without protection against insensitive economic use of land (agriculture, industrial construction, etc.).

\section{Conclusions}

Geophysical measurements proved to be beneficial even in urban, built-up terrains. For the reliability of such works, it is necessary to use a wider complex of geophysical methods (magnetometry, radar, ERT, DEMP, complex seismics and precise gravimetry are recommended).

Magnetometry disturbed by the presence of engineering networks, iron objects (streetlights, cars, etc.) requires a modified processing procedure. It is recommended to subtract the measured data from the regional field and then work with residual anomalies. Further work is being done to clarify this methodology.

A qualitative interpretation of geophysical anomalies is usually possible only in cooperation of a geophysicist with a given specialist (archaeologist, historian, and civil engineer). 
Most of the measurements found underground were archaeological structures. Their interpretation and chronology are only probable without subsequent archaeological discovery. However, geophysical findings allow the identified structures to be focused on directly without their laborious search, possibly to select those that promise interesting results.

For introductory work in developing countries (such as Armenia), a narrow complex of geophysical methods with instruments that do not require a large number of workers can be recommended. After obtaining basic knowledge from the site of interest, a more detailed project can be prepared.

Armenia has a large number of archaeological sites, from prehistoric to early medieval. This is a great cultural asset, but it is often insufficiently legally protected from devastation. Continuation of work in Armenia could contribute to the protection of monuments in this regard (construction of a protected tourist site, etc.).

Author Contributions: Conceptualization, J.B. and J.F.; methodology, J.B., J.J. and T.B.; software, T.F.; validation, J.B. and J.F.; investigation, J.J. and J.B.; data curation, J.J. and T.B.; writing-original draft preparation, J.B. and J.J.; writing-review and editing, J.B., J.J. and J.F.; supervision, J.F.; project administration, J.B. All authors have read and agreed to the published version of the manuscript.

Funding: This research received external funding of the Municipality of Prague, the Czech Development Agency and the Chironium Ltd. Company.

Acknowledgments: We would like to express our thanks to the Municipality of Prague for financial support of our geophysical activities in Prague. We would like to express our thanks to the Czech Development Agency for financial support of our geophysical activities in Armenia. We would like to express our thanks to the Institute of Archaeology and Ethnography of the National Academy of Sciences of the Republic of Armenia for support of our geophysical activities in Armenia. We would like to express our thanks to the Chironium Ltd. Company for the financial support of the Apostolus project. We would like to express our thanks to TSK Praha a. s. (Road Authority of Prague) for actual technical information of the Old Town Square, Hradčany Square and Lesser Town Square. We also thank to our colleagues from the Institute of Archaeology in Prague for reasonable cooperation, technical advising and selflessness.

Conflicts of Interest: The authors declare no conflict of interest.

\section{References}

1. SAGA Workshop 1. Available online: https://www.saga-cost.eu/meeting-abstracts.php?id_meeting=3 (accessed on 10 October 2019).

2. Reynolds, J.M. An Introduction to Applied and Environmental Geophysics, 2nd ed.; Wiley-Blackwell: Hoboken, NJ, USA, 2011.

3. Conyers, L.B. Ground-Penetrating Radar for Archaeology; Altamira Press: Lanham, MD, USA, 2013.

4. Deiana, R.; Leucci, G.; Martorana, R. New Perspectives on Geophysics for Archaeology: A Special Issue. Surv. Geophys. 2018, 39, 1035-1038. [CrossRef]

5. El-Qady, G.; Metwaly, M. (Eds.) Archaeogeophysics: State of Art and Case Studies; Springer: Berlin/Heidelberg, Germany, 2019.

6. Oswin, J. A Field Guide to Geophysics in Archaeology; Springer: Berlin/Heidelberg, Germany, 2009.

7. Ekinci, Y.L.; Kaya, M.A. 3D resistivity imaging of buried tombs at the Parion necropolis (NW Turkey). J. Balk. Geophys. Soc. 2007, 10, 1-8.

8. Beresneva, N.A.; Epimakhov, A.V.; Noskevich, V.V.; Fedorova, N.V.; Tkachev, V.V. Reconstruction of the Ancient Bronze Age Copper Quarries Using GPR. In Proceedings of the Near Surface Geoscience 2016-22nd European Meeting of Environmental and Engineering Geophysics, Barcelona, Spain, 4-8 September 2016; Volume 2016. cp-495-00127. [CrossRef]

9. Almutari, M. The Efficiency of Vertical Magnetic Gradient in the Discovery of Archaeological. In Proceedings of the 8th Congress of the Balkan Geophysical Society, Chania, Greece, 5-8 October 2015; Volume 2015, pp. 1-5. [CrossRef]

10. Brion, C. Gallo-Roman Site of Grand: A Comparison between Archaeological and Geophysical Data for Spatial Analysis. In Proceedings of the Near Surface Geoscience 2012-18th European Meeting of Environmental and Engineering Geophysics, Paris, France, 3-5 September 2012. 
11. Baker, G.S. Processing Near Surface Seismic-Reflection Data: A Primer; Society of Exploration Geophysicist: Tulsa, OK, USA, 1999.

12. Butler, D.K. Near-Surface Geophysics; Society of Exploration Geophysics: Tulsa, OK, USA, 2005. [CrossRef]

13. Everett, M.E. Near-Surface Applied Geophysics; Springer Science \& Business Media: Dordrecht, The Netherlands, 2014.

14. Barta, J.; Jirku, J.; Belov, T. A Complex Geophysical Survey at the Old Town Square in Prague. In Proceedings of the SAGA Workshop, Prague, Czech Republic, 30 September-1 October 2019; Available online: https: //www.saga-cost.eu/meeting-abstracts.php?id_meeting=3 (accessed on 10 October 2019).

15. Barta, J.; Belov, T.; Jirku, J. Geophysical-Archaeological Survey at the Hradčany Square in Prague. In Proceedings of the SAGA Workshop, Prague, Czech Republic, 30 September-1 October 2019; Available online: https://www.saga-cost.eu/meeting-abstracts.php?id_meeting=3 (accessed on 10 October 2019).

16. Jirku, J.; Belov, T. Initial Geophysical Surveying of Archaeological Sites in Armenia. In Proceedings of the SAGA Workshop, Prague, Czech Republic, 30 September-1 October 2019; Available online: https: //www.saga-cost.eu/meeting-abstracts.php?id_meeting=3 (accessed on 10 October 2019).

17. Podliska, J. Příspěvek archeologie k poznání podoby kaple Božího Těla na Karlově náměstí v Praze-Der Beitrag der Achäologie zur Erkenntnis der Gestalt der Fronleichnamskapelle am Platz Karlovo náměstí in Prag. Staletá Praha 2013, 29, 2-20.

18. Havrda, J.; Kočár, P.; Kočárová, R.; Kozáková, R.; Podliska, J.; Sůvová, Z. K vývoji historického nadloží Staroměstského náměstí v Praze. Příspěvek k mezioborovému výzkumu veřejných prostranství—On the Development and Situation of the Historic Overburden of Old Town Square in Prague. A Contribution to Interdisciplinary Research of Public Space. Forum urbes medii aevii 2017, IX, 160-191.

19. Blažková, G.; Matiášek, J.; Kozáková, R.; Kočár, P. Raně středověké opevnění na Hradčanech v Praze. Nové poznatky na základě výzkumů z let 2011 a 2013-Die frühmittelalterliche Befestigung in Hradschin in Prag. Neue Erkenntnisse anhand der Forschungen aus den Jahren 2011 und 2013. Staletá Praha 2015, 31, $16-41$.

20. Mašterová, K. Objev druhé románské stavby na Hradčanech—Discovery of the Second Romanesque Building at Hradčany. In Profil Archeologie středověku: Studie věnované Janu Frolikovi; Kapustka, K., Ed.; Archeologický ústav AV ČR: Praha, Czech Republic, 2018; pp. 87-103.

21. Frolík, J. Archeologický výzkum na Hradčanském náměstí v r. 1944-Archaeological Excavations at Hradčanské náměstí/Hradčany Square/ in 1944. Castrum Pragense 1988, 1, 137-175.

22. Čiháková, J. Die Rotunde des hl. Wenzels in Prag-Kleinseite-Ihre Gestalt, Projekt sowie Vorgänger. In Architektura w poczatkach państw Europy Środkowej / Architecture in the Early Period of the States of Central Europe; Tomasz, J., Dariusz, S., Eds.; Museum Pierwszych Piastow: Gniezdno, Poland, 2018; pp. 151-174.

23. Čiháková, J. The Lesser Town of Prague in the Tenth and Eleventh Centuries. In Moravian and Silesian Strongholds of the Tenth and Eleventh Centuries in the Context of Central Europe; Kouřil, P., Procházka, R., Eds.; Spisy Archeologického ústavu AV ČR: Brno, Czech Republic, 2018; Volume 57, pp. 283-303.

24. Cymbalak, T.; Podliska, J. New Discoveries of Early Medieval Streets in Lesser Town in Prague. Contribution to Knowledge of Communications Network of Suburbium of the Prague Castle. In Ulica, plac i cmentarz w publicznej przestrzeni średniowiecznego i wczesnonowożytnego miasta Europy Środkowej-Strasse, Platz und Friedhof in dem öffentlichen Raum der mittelalterlichen und frühneuzeitlichen Stadt Mitteleuropas; Krabath, S., Piekalski, J., Wachowski, K., Eds.; Wratislavia Antiqua: Wrocław, Poland, 2011; Volume 13, pp. 299-309.

25. Simonyan, H. (Ed.) Archaeological Heritage of Armenia; Ministry of Culture of the Republic of Armenia: Yerevan, Armenia, 2013.

26. Archaeology of Armenia in Regional Context; Avetisyan, P.; Bobokhyan, A. (Eds.) Institute of Archaeology and Ethnography NASRA: Yerevan, Armenia, 2012.

27. Hrubec, K. Strahov; Geophysical Report; G IMPULS Praha spol. s r.o.: Praha, Czech Republic, 1996.

28. Budinský, V. MVE Mladé Buky; Geophysical Report; G IMPULS Praha spol. s r.o.: Praha, Czech Republic, 2007.

(C) 2020 by the authors. Licensee MDPI, Basel, Switzerland. This article is an open access article distributed under the terms and conditions of the Creative Commons Attribution (CC BY) license (http://creativecommons.org/licenses/by/4.0/). 